\title{
Catalytic performance of different types of iron zeolites in $\mathrm{N}_{2} \mathrm{O}$ decomposition
}

\author{
WANG Junying a,b, XIA Haian a, JU Xiaohua a , FAN Fengtao a , FENG Zhaochi a , LI Can ${ }^{\text {a,* }}$ \\ a State Key Laboratory of Catalysis, Dalian Institute of Chemical Physics, Chinese Academy of Sciences, Dalian 116023, Liaoning, China \\ b Graduate University of Chinese Academy of Sciences, Beijing 100049, China
}

A R T I C L E I N F O

Article history:

Received 26 December 2012

Accepted 24 February 2013

Published 20 May 2013

\section{Keywords:}

Iron

Zeolite

Nitrous oxide decomposition

Raman spectroscopy

\begin{abstract}
A B S T R A C T
A series of Fe/zeolites (ZSM-35, ZSM-5, beta, and mordenite) samples with Fe/Al molar ratios of 0.33 were prepared using a solid-state ion-exchange method. A combination of ultraviolet-visible diffuse reflectance, in-situ Fourier-transform infrared, and in-situ visible Raman spectroscopic techniques, with a transient response method, was used to investigate the influence of the zeolite framework on the catalytic properties of the Fe/zeolites in $\mathrm{N}_{2} \mathrm{O}$ decomposition. The results show that the catalytic activity of the Fe/zeolites-HT (HT denotes high-temperature treatment) samples is in the order Fe/ZSM-35-HT > Fe/beta-HT > Fe/ZSM-5-HT > Fe/mordenite-HT. There is a linear relationship between the rate of $\mathrm{N}_{2} \mathrm{O}$ decomposition and the concentration of binuclear iron sites. This indicates that binuclear iron sites are the active sites for $\mathrm{N}_{2} \mathrm{O}$ decomposition. A correlation between the formation of binuclear iron sites and Fe ion distribution among the cationic sites is proposed. Two Fe(II) cations located in two adjacent six-membered rings in a 10-membered ring channel ( $\alpha$ sites) or in two neighboring six-membered rings in an eight-membered ring channel $(\beta$ sites) of Fe/ZSM-35 are favorable for the formation of active binuclear iron sites. Similar structure can also be formed in two adjacent six-membered rings in polymorphs A and B of beta zeolite or in the six-membered rings at the intersection of the straight and sinusoidal channels of the ZSM-5 framework. For the Fe/mordenite-HT sample, most of the iron species are present as isolated iron cations, so it has the lowest activity in $\mathrm{N}_{2} \mathrm{O}$ decomposition.
\end{abstract}

(C) 2013, Dalian Institute of Chemical Physics, Chinese Academy of Sciences. Published by Elsevier B.V. All rights reserved.

\section{Introduction}

Iron-containing zeolites are known to be excellent catalysts for the decomposition of harmful $\mathrm{N}_{2} \mathrm{O}$ to nitrogen and oxygen $[1,2]$. Since the early work performed in Panov's laboratory, Fe/ZSM-5 has been extensively studied experimentally and theoretically [3-6]. The experimental and theoretical studies have concentrated on the influence of the preparation method and the mode of pretreatment on the structure and properties of the active sites in Fe/ZSM-5 catalysts [3-6]. Far fewer studies have investigated the decomposition of $\mathrm{N}_{2} \mathrm{O}$ over other $\mathrm{Fe} /$ zeolite samples [7-13].

Øygarden et al. [7] found that the activity of commercial BEA zeolite in direct $\mathrm{N}_{2} \mathrm{O}$ decomposition was higher than those of FER and MFI; all have iron impurities. This is probably a result of the displacement of $\mathrm{Fe}$ and $\mathrm{Al}$ from the lattice, resulting in the formation of active bi- and oligo-nuclear iron sites. Kaucký et al. [8] reported that the shorter Fe-Fe distances in

\footnotetext{
* Corresponding author. Tel: +86-411-84379070; Fax: +86-411-84694447; E-mail: canli@dicp.ac.cn This work was supported by the National Natural Science Foundation of China (21173213) and the National Basic Research Program of China (973 Program, 2009CB623507).
} 
Fe/FER cause higher activity in $\mathrm{N}_{2} \mathrm{O}$ decomposition compared with that of $\mathrm{Fe} /$ beta. On the basis of spectroscopic techniques and density functional theory calculations, Jíša et al. $[9,10]$ provided evidence that two Fe(II) cations accommodated in two adjacent six-membered rings in the eight-membered ring channel of $\mathrm{Fe} /$ ferrierite were probably responsible for its superior activity compared with $\mathrm{Fe} /$ beta and $\mathrm{Fe} / \mathrm{MFI}$ in $\mathrm{N}_{2} \mathrm{O}$ decomposition. An advantage of Fe/FER over Fe/BEA, Fe/ZSM-5, and Fe/FAU was found by Pantu et al. [11] and was ascribed to the smaller pores and slightly stronger adsorption properties of $\mathrm{N}_{2} \mathrm{O}$ on FER zeolite. In a comparison of Fe/MFI and Fe/BEA with similar iron species, Pérez-Ramírez et al. [12] claimed that the microporous matrix does not play a decisive role in direct $\mathrm{N}_{2} \mathrm{O}$ decomposition. Melián Cabrera et al. [13] reported that the activity of Fe/FER was better than those of Fe/MFI and Fe/BEA in the simulated tail gas of nitric acid plants; this probably originated from the generation and stabilization of active iron sites in Fe/FER. However, little information is available on the effect of zeolite structure on the catalytic performance of $\mathrm{Fe}$ /zeolites in $\mathrm{N}_{2} \mathrm{O}$ abatement.

It has been reported that isolated cationic iron species, diand oligo-meric iron species, oligonuclear Fe-0-Al mixed oxides, and large iron oxide nanoparticles on the external surface of the zeolite are all potentially active sites for $\mathrm{N}_{2} \mathrm{O}$ decomposition [14]. The structure of the active sites is related to the specific synthesis and activation procedures and/or to a particular confinement of the iron species imposed by the microporous structure of the zeolite. Wicherlová's group [15-19] suggested that Co(II) ions mainly occupy three main cationic sites, $\alpha, \beta$, and $\gamma$, in high-silica pentasil ring zeolites (FER, MFI, BEA, and MOR), based on Fourier-transform infrared (FT-IR) and ultraviolet-visible (UV-Vis) diffuse reflectance spectroscopy using $\mathrm{Co}(\mathrm{II})$ ions as a probe. The suggested locations of the Co(II) ions in $\alpha, \beta$, and $\gamma$ sites in high-silica pentasil ring zeolites are further supported by the identification of $\mathrm{Cu}(\mathrm{II})$ ions at $\alpha$ cationic framework sites in mordenite [20] and of Ni(II) ions at $\beta$ cationic framework sites in Ni-ferrierite [21]; these results were obtained using single-crystal X-ray diffraction and synchrotron powered X-ray diffraction, respectively. The spatial arrangement of divalent transition-metal ions in pentasil ring zeolites is therefore universal.

The structures of the active iron sites in Fe/zeolites, particularly Fe/ZSM-5 and Fe/ZSM-35, have been studied by Li's Group [22,23]. It is found that binuclear iron sites are the active sites for $\mathrm{N}_{2} \mathrm{O}$ decomposition in Fe/ZSM-5 and Fe/ZSM-35. In this work, a combination of various spectroscopic techniques was used to investigate the catalytic properties of Fe-containing zeolites with different structures in $\mathrm{N}_{2} \mathrm{O}$ decomposition.

\section{Experimental}

\subsection{Catalyst preparation}

$\mathrm{Fe} /$ zeolites samples with $\mathrm{Fe} / \mathrm{Al}$ molar ratios of 0.33 were prepared using a solid-state ion-exchange method. $\mathrm{NH}_{4}^{+}$/zeolite ( $2 \mathrm{~g}$ ) was calcined at $823 \mathrm{~K}$ for $2 \mathrm{~h}$ in flowing he- lium. The reactor was then cooled to room temperature, sealed, and placed in a glove box. The reactor was opened in the glove box, and the resulting $\mathrm{H}$ /zeolite was removed and ground with an appropriate amount of anhydrous $\mathrm{FeCl}_{3}$ (Sigma-Aldrich, AR) in a mortar. The mixture was returned to the reactor, and the reactor was resealed and removed from the glove box. The reactor was heated to $598 \mathrm{~K}$ and kept at this temperature for 2 h. The resulting solid was treated in a flow of $0.5 \% \mathrm{H}_{2} \mathrm{O}$ in helium from room temperature to $498 \mathrm{~K}$ to hydrolyze the $\mathrm{Fe}-\mathrm{Cl}$ bonds. Finally, the sample was calcined at $823 \mathrm{~K}$ for $2 \mathrm{~h}$ in a flow of oxygen; the sample was denoted Fe/zeolite-C, where $\mathrm{C}$ refers to calcination in $\mathrm{O}_{2}$. A fraction of $\mathrm{Fe} /$ zeolite was further treated at $1173 \mathrm{~K}$ for $2 \mathrm{~h}$ in flowing helium to obtain $\mathrm{Fe} /$ zeolite-HT, where HT denotes high-temperature treatment. $\mathrm{NH}_{4}+$ ZSM-5 $\left(\mathrm{SiO}_{2} / \mathrm{Al}_{2} \mathrm{O}_{3}=25\right), \mathrm{NH}_{4}+$ / beta $\left(\mathrm{SiO}_{2} / \mathrm{Al}_{2} \mathrm{O}_{3}=26\right)$, $\mathrm{NH}_{4}+/ \mathrm{ZSM}-35 \quad\left(\mathrm{SiO}_{2} / \mathrm{Al}_{2} \mathrm{O}_{3}=21\right)$, and $\mathrm{NH}_{4}+$ /mordenite $\left(\mathrm{SiO}_{2} / \mathrm{Al}_{2} \mathrm{O}_{3}=23\right)$ were used.

\subsection{Catalyst characterization}

The chemical compositions of the catalysts were determined using inductively coupled plasma-atomic emission spectrometry.

X-ray diffraction (XRD) data were collected using a Rigaku D/MAX 2500 diffractometer $\left(40 \mathrm{kV}, 200 \mathrm{~mA}, \mathrm{Cu} K_{\alpha}\right.$ radiation). The step size was $0.02^{\circ}$ and the scan speed was $5^{\circ} / \mathrm{min}$.

UV-Vis diffuse reflectance spectra were collected at room temperature using a JASCO V-550 UV-visible spectrometer $\left(\mathrm{BaSO}_{4}\right.$ was used as a reference). Deconvolution of the UV-visible absorbance bands into Gaussian sub-bands, followed by multiplying the percentage of sub-bands with respect to the total area of the experimental spectrum with the total iron content, gives the percentage of different Fe species in the $\mathrm{Fe} /$ zeolites-C samples [12]. This quantification method does not account for the dependences of the extinction coefficients of various iron species on the wavelength but nevertheless provides a semi-quantitative estimation of the distributions of the various Fe species.

FT-IR spectra were recorded using a Nicolet Impact FT-IR spectrometer with a mercury cadmium telluride detector in transmission mode at a resolution of $4 \mathrm{~cm}^{-1}$. The $\mathrm{Fe} /$ zeolites samples were pressed into self-supporting wafers (ca. 10 $\mathrm{mg} / \mathrm{m}^{2}$ ) and placed in a quartz IR cell with two $\mathrm{CaF}_{2}$ windows. The Fe/zeolites-C samples were pretreated at $623 \mathrm{~K}$ for $1 \mathrm{~h}$ in flowing $\mathrm{O}_{2}$, and the $\mathrm{Fe}$ /zeolites-HT samples were pretreated in a helium flow for $1 \mathrm{~h}$. A reference spectrum was recorded. The samples were then cooled to room temperature in the same gas flow. The in-situ pretreated samples were exposed to $1.0 \%$ $\mathrm{NO} / \mathrm{He}$ and then purged with helium. The gas flow rate was 60 $\mathrm{ml} / \mathrm{min}$. The intensity of each IR spectrum was normalized at the overtones of the zeolite lattice (1500-2000 $\left.\mathrm{cm}^{-1}\right)$.

Visible Raman spectra were recorded in situ on a laboratory-made triple-stage Raman spectrometer with an excitation laser line at $532 \mathrm{~nm}$ emitted from a semiconductor laser. The sample was pressed into a self-supporting wafer and placed in an in-situ quartz cell. The sample was first calcined in $\mathrm{O}_{2}$ at 823 $\mathrm{K}$ for $1 \mathrm{~h}$, followed by treatment in helium at $1173 \mathrm{~K}$ for $1 \mathrm{~h}$. A 
flow of $5.0 \% \mathrm{~N}_{2} \mathrm{O} / \mathrm{He}$ was then introduced into the quartz cell. After each treatment, the sample was cooled to room temperature to record the Raman spectrum.

A transient response method was used to measure the concentrations of active iron sites. The Fe/zeolites-C samples were pretreated in $\mathrm{O}_{2}$ at $823 \mathrm{~K}$ for $1 \mathrm{~h}$, and the Fe/zeolites-HT samples were pretreated in helium at $1173 \mathrm{~K}$ for $1 \mathrm{~h}$. The sample was then cooled in flowing helium to the temperature of the transient response experiment. The tail gas was continuously monitored in the reactor outlet after switching from a helium flow to a $5.0 \% \mathrm{~N}_{2} \mathrm{O} / \mathrm{He}$ flow. The quantity of active $\mathrm{Fe}(\mathrm{II})$ sites was calculated by integration of the $\mathrm{N}_{2}$ evolved.

\subsection{Activity measurements}

Catalytic decomposition of $\mathrm{N}_{2} \mathrm{O}$ over the Fe/zeolites-C/HT catalysts was carried out in a U-shaped quartz reactor with an inner diameter of $4 \mathrm{~mm}$. About $50 \mathrm{mg}$ of catalyst were placed between two quartz-wool plugs; the gas mixture was $5.0 \%$ $\mathrm{N}_{2} \mathrm{O} / \mathrm{He}$ at a gas head space velocity of $24000 \mathrm{~h}^{-1}$. An on-line mass spectrometer (Gam 200, Pfeiffer Vacuum) was used for

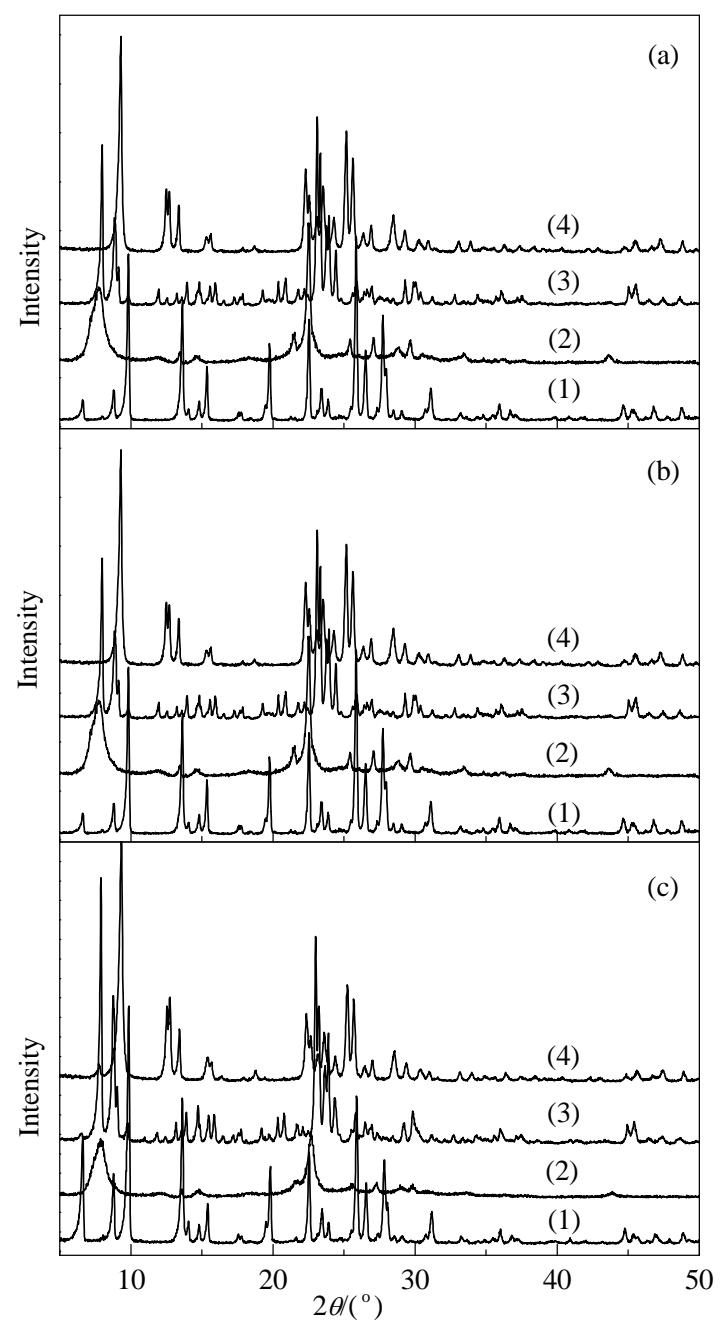

Fig. 1. XRD patterns of $\mathrm{H}$ /zeolites (a), Fe/zeolites- $\mathrm{C}$ (b), and Fe/zeolites-HT (c) samples. (1) H(Fe)/mordenite; (2) H(Fe)/beta; (3) $\mathrm{H}(\mathrm{Fe}) / \mathrm{ZSM}-35$; (4) H(Fe)/ZSM-5. quantitative analysis of tail gas compositions.

\section{Results and discussion}

\subsection{Characterization of $\mathrm{H}(\mathrm{Fe}) /$ zeolites}

Figure 1(a) presents the XRD patterns of the $\mathrm{H} /$ mordenite, H/beta, H/ZSM-35, and H/ZSM-5 zeolites. The expected diffraction patterns for the various zeolite structures and good crystallinities are observed for all the H/zeolites. For the $\mathrm{Fe} /$ zeolites-C/HT samples, only XRD reflections assigned to zeolite frameworks are observed, and no XRD patterns ascribed to iron oxide nanoparticles appear (Fig. 1(a) and (c)). This indicates that the long-range order of the zeolite frameworks is not affected, and high dispersion of iron species on the zeolites is obtained.

\section{2. $U V$-visible diffuse reflectance spectra of $\mathrm{Fe} /$ zeolites}

The coordination environments of various Fe species in $\mathrm{Fe} /$ zeolites-C/HT samples were characterized using UV-Vis diffuse reflectance spectroscopy. Figure 2(a) displays the $\mathrm{UV}$-Vis diffuse reflectance spectra of $\mathrm{Fe} /$ zeolites-C samples. The UV-Vis diffuse reflectance spectrum of $\mathrm{Fe} /$ mordenite- $\mathrm{C}$ shows three intense $\mathrm{Fe}$ (III) $\leftarrow 0$ charge-transfer (CT) bands at 240 , 275 , and $360 \mathrm{~nm}$, as well as a very weak shoulder at $540 \mathrm{~nm}$. For the Fe/beta-C and Fe/ZSM-5-C samples, two intense ligand-to-metal CT bands at 240 and $360 \mathrm{~nm}$ and a smaller contribution at $540 \mathrm{~nm}$ appear. The Fe/ZSM-35-C sample also exhibits absorption bands at 240,275, 360, and $540 \mathrm{~nm}$, and the

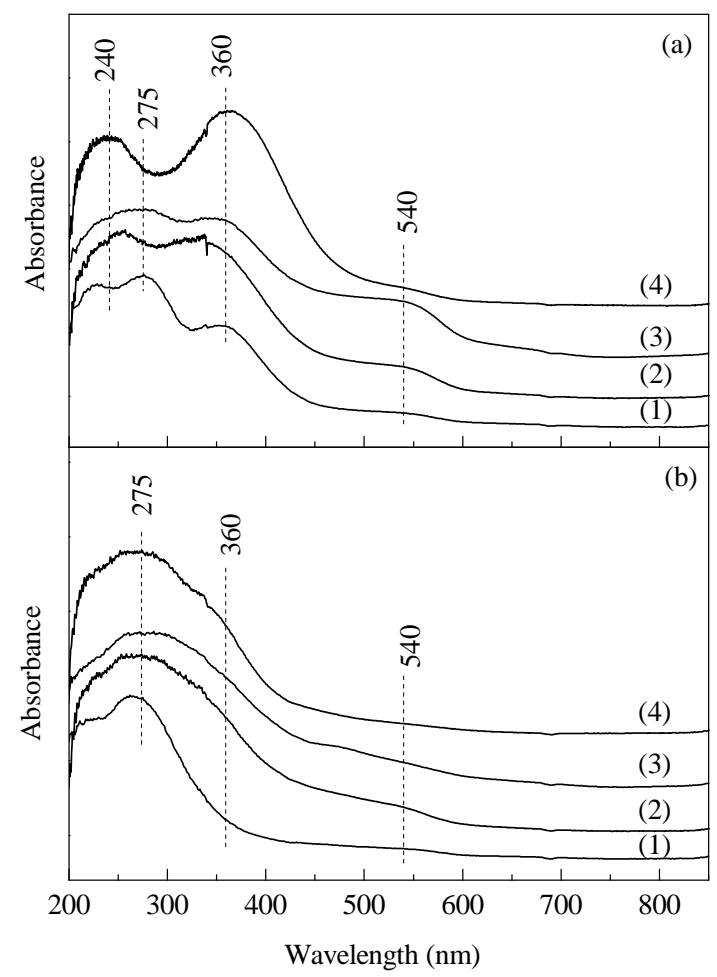

Fig. 2. UV-Vis diffuse reflectance spectra of $\mathrm{Fe} /$ zeolites-C (a) and Fe/zeolites-HT (b) samples. (1) Fe/mordenite; (2) Fe/beta; (3) Fe/ZSM-35; (4) Fe/ZSM-5. 
Table 1

Percentage of the area of sub-bands $\left(I_{1}\right.$ at $\lambda<300 \mathrm{~nm}, I_{2}$ at $300<\lambda<400$ $\mathrm{nm}, I_{3}$ at $\lambda>400 \mathrm{~nm}$ ) of UV-visible diffuse reflectance spectra (Fig. 2(a)) and corresponding Fe mass percentage derived from total Fe content in Fe/zeolites-C.

\begin{tabular}{|c|c|c|c|c|c|c|c|}
\hline \multirow{2}{*}{ Catalyst } & \multirow{2}{*}{$\frac{\mathrm{Fe}^{\mathrm{a}}}{w / \%}$} & \multicolumn{2}{|c|}{$\mathrm{Fe}^{\mathrm{b}}$} & \multicolumn{2}{|c|}{$\mathrm{Fe}^{\mathrm{c}}$} & \multicolumn{2}{|c|}{$\mathrm{Fe}^{\mathrm{d}}$} \\
\hline & & $I_{1}$ & $w / \%$ & $I_{2}$ & $w / \%$ & $I_{3}$ & $w / \%$ \\
\hline $\mathrm{Fe} /$ mordenite-C & 1.0 & 54 & 0.55 & 33 & 0.33 & 13 & 0.13 \\
\hline $\mathrm{Fe} / \mathrm{ZSM}-5-\mathrm{C}$ & 1.1 & 32 & 0.38 & 64 & 0.77 & 4 & 0.05 \\
\hline $\mathrm{Fe} /$ beta-C & 1.1 & 23 & 0.28 & 65 & 0.78 & 12 & 0.14 \\
\hline Fe/ZSM-35-C & 1.5 & 49 & 0.74 & 24 & 0.36 & 27 & 0.40 \\
\hline
\end{tabular}

a Determined by ICP. ${ }^{\mathrm{b}}$ Isolated Fe ions in tetrahedral and octahedral coordination. ${ }^{\mathrm{c}}$ Oligo-nuclear $\mathrm{Fe}_{x} \mathrm{O}_{y}$ clusters $(x \geq 2)$. ${ }^{\mathrm{d}}$ Bulk Fe oxides.

intensity of the absorption band at $540 \mathrm{~nm}$ is significantly higher than those of the other three $\mathrm{Fe}$ /zeolites-C samples. Figure 2(b) presents the UV-Vis diffuse reflectance spectra of the Fe/zeolites-HT samples. The intensity of the CT band at 275 $\mathrm{nm}$ is higher, whereas those of the absorption bands centered at about 240, 360, and $540 \mathrm{~nm}$ are lower than those in the $\mathrm{Fe} /$ zeolites-C samples, indicating that high-temperature treatment induces significant changes in iron speciation in all the $\mathrm{Fe} /$ zeolites samples.

In the literature, the CT bands between 200 and $300 \mathrm{~nm}$ are typically assigned to isolated Fe species with tetrahedral or higher coordinations [24-27], the broad bands between 300 and $450 \mathrm{~nm}$ are assigned to small oligomeric $\mathrm{Fe}_{x} \mathrm{O}_{y}$ clusters, and the bands above $450 \mathrm{~nm}$ are assigned to large iron oxide aggregates [28]. We therefore ascribe the absorption bands at 240 and $275 \mathrm{~nm}$ to Fe(III) $\leftarrow 0$ CT of tetrahedrally coordinated Fe ions and octahedrally coordinated Fe ions, respectively. The band at $360 \mathrm{~nm}$ is related to oligonuclear Fe species, and the band at about $540 \mathrm{~nm}$ arises from bulky iron oxide nanoparticles. On high-temperature activation, the amount of isolated iron species in octahedral coordination increases, and the quantity of oligomeric iron clusters and large $\mathrm{Fe}_{x} \mathrm{O}_{y}$ particles decreases. The relative amounts of different iron species are listed in Table 1. The relative quantities of isolated and oligomeric $\mathrm{Fe}$ species in the $\mathrm{Fe} /$ zeolites- $\mathrm{C}$ samples are in the order Fe/ZSM-35-C > Fe/ZSM-5-C > Fe/beta- $\mathrm{C}$ Fe/mordenite-C, suggesting that iron species are present mainly as isolated and oligonuclear cationic species in the zeolite micropores or on the external surface of the zeolite.

\subsection{IR spectra of NO adsorption on Fe/zeolites samples}

Figure 3(a) and (b) shows the IR spectra in the region 1500-1900 $\mathrm{cm}^{-1}$ after exposure of the Fe/zeolites-C/HT samples to NO for $30 \mathrm{~min}$ and then purging in a flow of helium. An IR band at $1626 \mathrm{~cm}^{-1}$ with shoulder bands at 1610 and 1580 $\mathrm{cm}^{-1}$ can be observed for the Fe/zeolites-C samples. Significant changes take place in the IR spectra of the catalysts treated in helium at $1173 \mathrm{~K}$. Besides the IR band at $1626 \mathrm{~cm}^{-1}$ with a shoulder band at $1580 \mathrm{~cm}^{-1}$, a new characteristic IR band at $1874 \mathrm{~cm}^{-1}$ appears. For the Fe/ZSM-5-HT catalyst, another IR band at $1892 \mathrm{~cm}^{-1}$ is observed. Based on the literature data, the bands at 1580, 1610, and $1626 \mathrm{~cm}^{-1}$ are assigned to monodentate/bidentate nitro or nitrate species adsorbed on iron oxide

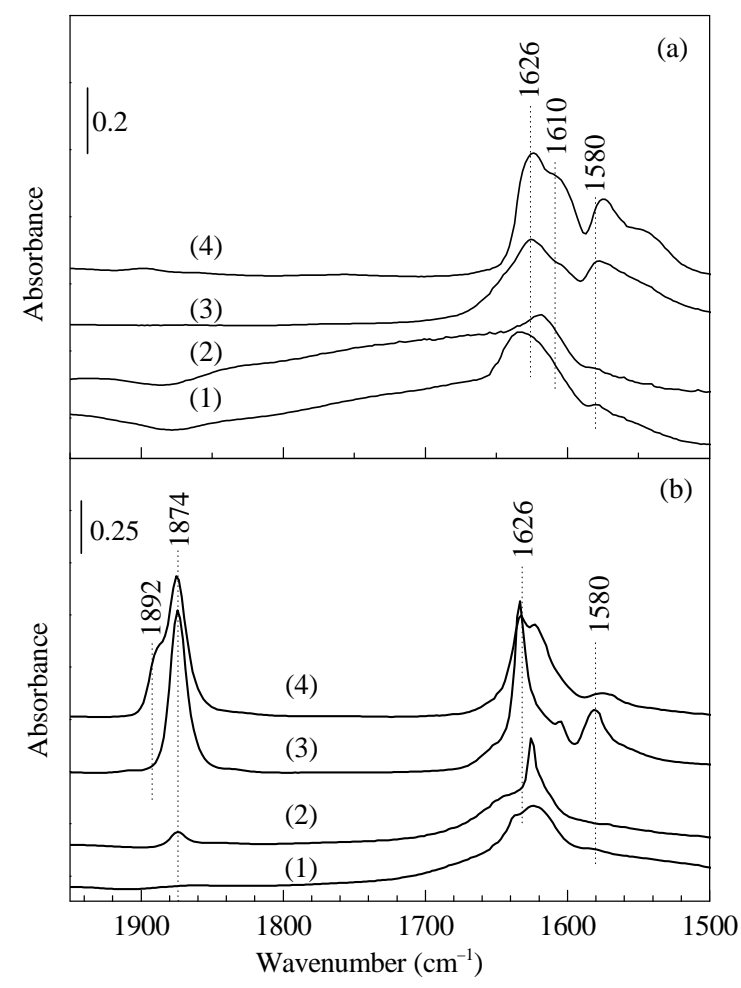

Fig. 3. FT-IR spectra of adsorbed NO on Fe/zeolites-C (a) and Fe/zeolites-HT (b) samples. (1) Fe/mordenite; (2) Fe/beta; (3) Fe/ZSM-35; (4) Fe/ZSM-5.

species [29-31]. One explanation for the appearance of the nitro and nitrate species could be that some oxidation of NO by residual oxygen or extra-framework oxygen to $\mathrm{N}_{2} \mathrm{O}_{4}, \mathrm{NO}_{2}, \mathrm{NO}^{3-}$, or $\mathrm{NO}^{2-}$ occurs, or very small amounts of $\mathrm{NO}_{2}$ are present in the NO probe gas. The strong IR band at $1874 \mathrm{~cm}^{-1}$ arises from NO adsorbed on Fe cations of the extra-framework Fe-O-Al oxide clusters [22], and the shoulder band at $1892 \mathrm{~cm}^{-1}$ is ascribed to mononitrosyl species formed on isolated or oligonuclear iron species [32]. These two IR bands correspond to the adsorption of NO on Fe(II) sites, not on Fe(III) sites [33]. From the results presented above, it appears that the cationic iron species that initially compensate for the negative framework charge of the Al-occupied oxygen tetrahedra are partially transformed into extra-framework $\mathrm{Fe}-\mathrm{O}-\mathrm{Al}$ oxide clusters upon high temperature treatment; this is very important for $\mathrm{N}_{2} \mathrm{O}$ decomposition [22].

\subsection{Visible Raman spectra of Fe/zeolites samples}

Visible resonance Raman spectroscopy has proven to be a very powerful tool for the identification of the active oxygen species in $\mathrm{Fe} / \mathrm{zeolites,}$ such as $\mathrm{Fe}_{2}\left(\mu-1,2-\mathrm{O}_{2}\right)$ species in $\mathrm{Fe} / \mathrm{ZSM}-5$ and $\mathrm{Fe}_{2}(\mu-0)_{2}$ species in Fe/ZSM-35 [23,34]. Tuning a laser near or into the characteristic absorption feature of the sample leads to in-resonance or resonance enhancement of Raman bands associated only with this chromophore, the intensity of which can be increased as much as $10^{4-10^{6}}$ fold compared with normal Raman scattering [35,36]. Figure 4(a) shows the visible Raman spectra, excited at $532 \mathrm{~nm}$, of the 


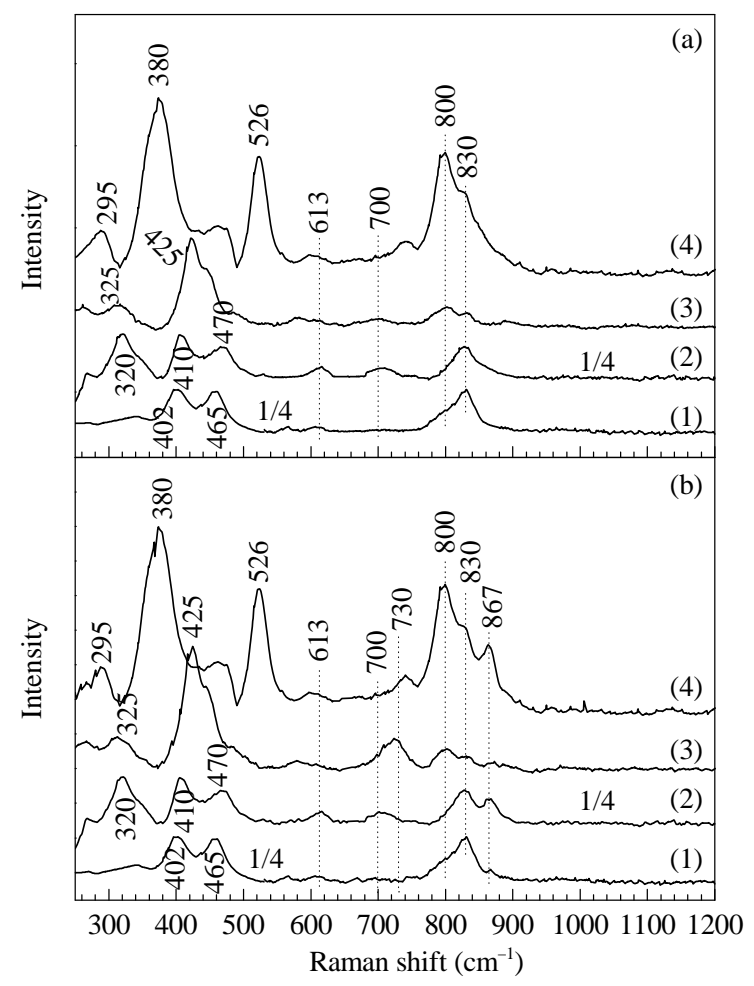

Fig. 4. Visible Raman spectra recorded in situ of Fe/zeolites-HT samples (a) and after exposure of (a) to $5.0 \% \mathrm{~N}_{2} \mathrm{O} / \mathrm{He}$ at $523 \mathrm{~K}$ (b). (1) Fe/mordenite-HT; (2) Fe/beta-HT; (3) Fe/ZSM-35-HT; (4) Fe/ZSM-5 -HT. The excitation laser line: $532 \mathrm{~nm}$.

Fe/zeolites-HT samples. The Raman spectrum of $\mathrm{Fe}$ /mordenite-HT has bands centered at 402, 465, 800, and 830 $\mathrm{cm}^{-1}$, which are the characteristic bands of the MOR structure [37-39]. The Raman spectrum of the Fe/beta-HT presents new bands at $320,410,470,613,700$, and $830 \mathrm{~cm}^{-1}$. The Raman bands at 320,410 , and $470 \mathrm{~cm}^{-1}$ are assigned to bending modes of five-membered, six-membered, and four-membered rings, respectively [40]. The band at $830 \mathrm{~cm}^{-1}$ is often associated with symmetric stretching vibrations of $\mathrm{Si}-\mathrm{O}$ bonds [41]. The bands at 613 and $700 \mathrm{~cm}^{-1}$ probably correspond to some iron oxides and oxyhydroxides [42], or to the $\mathrm{Si}-\mathrm{O}$ bonds of a non-crystalline $\mathrm{Si}-0$ matrix surrounding the domains of the BEA structure $[43,44]$. The spectrum of Fe/ZSM-35-HT has bands at $325,425,800$, and $830 \mathrm{~cm}^{-1}$, which are characteristic of the ZSM-35 framework [43,45-48]. For Fe/ZSM-5-HT, in addition to the characteristic bands of the MFI structure at 295, 380,460 , and $800 \mathrm{~cm}^{-1}$, a new band at $526 \mathrm{~cm}^{-1}$ is observed. This band is attributed to symmetric stretching vibrations of an Fe-0-Fe cluster of low nuclearity [22,49]. After exposure of the $\mathrm{Fe} /$ zeolites-HT samples to $5.0 \% \quad \mathrm{~N}_{2} \mathrm{O} / \mathrm{He}$ at $523 \mathrm{~K}$, $\mathrm{Fe} /$ mordenite-HT, Fe/beta-HT, and Fe/ZSM-5-HT exhibit a new Raman band at $867 \mathrm{~cm}^{-1}$, and Fe/ZSM-35-HT shows a new Raman band at $730 \mathrm{~cm}^{-1}$ (Fig. 4(b)). The Raman bands at 867 and $730 \mathrm{~cm}^{-1}$ are attributed to peroxide species bridging binuclear Fe sites [34] and symmetric stretching vibrations of binuclear $\mathrm{Fe}_{2}(\mu-\mathrm{O})$ sites, respectively [23]. Almost no Raman band corresponding to binuclear Fe sites can be observed in the spectrum of $\mathrm{Fe} /$ mordenite-HT.

\subsection{Concentrations of active Fe sites in Fe/zeolites samples}

The concentrations of active Fe sites were determined using a transient response method. Fig. 5(a) shows the product-time profiles in the reactor outlet after switching from a helium flow to a $5.0 \% \mathrm{~N}_{2} \mathrm{O} / \mathrm{He}$ flow for the Fe/ZSM-5-HT sample. Only $\mathrm{N}_{2}$ and $\mathrm{N}_{2} \mathrm{O}$ appear in the outlet, indicating the formation of surface oxygen atoms during $\mathrm{N}_{2} \mathrm{O}$ decomposition at low temperature. Similar experiments using the Fe/zeolites-C samples revealed that the amount of $\mathrm{N}_{2}$ evolved was negligible, suggesting that high-temperature activation is a prerequisite for the formation of active Fe sites [22]. The concentration of active Fe sites per gram of a Fe/zeolite-HT sample can be obtained by integrating the peak of the $\mathrm{N}_{2}$ released; the results are listed in Table 2. The concentrations of active Fe sites in the $\mathrm{Fe} /$ zeolites-HT samples are in the order Fe/ZSM-35-HT > $\mathrm{Fe} /$ beta-HT $>\mathrm{Fe} / \mathrm{ZSM}-5-\mathrm{HT}>\mathrm{Fe} /$ mordenite-HT; this is in agreement with the FT-IR spectra. The intensity of the IR band at $1874 \mathrm{~cm}^{-1}$ has a proportional linear relation with the concentration of active iron sites (Fig. 5(b)). The FT-IR and visible Raman spectra, combined with the transient response experimental results, indicate that binuclear iron sites stabilized by
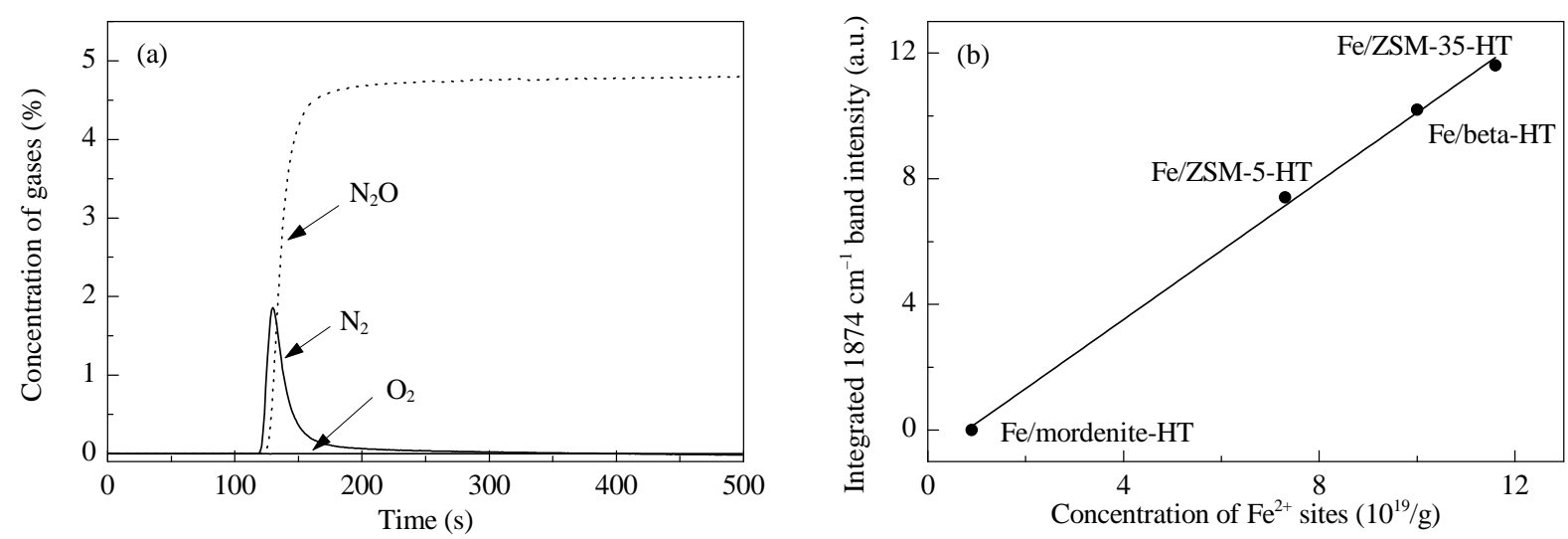

Fig. 5. (a) Product-time profiles in the reactor outlet after a step change from He flow to $5.0 \% \mathrm{~N}_{2} \mathrm{O} / \mathrm{He}$ flow at $523 \mathrm{~K}$ on Fe/ZSM-5-HT sample; (b) Dependence of the integrated $1874 \mathrm{~cm}^{-1}$ band intensity on the concentration of active Fe sites determined by the transient response method for $\mathrm{Fe} /$ zeolites-HT samples. 
Table 2

Concentration of active Fe sites determined by the transient response method and the reaction rate of $\mathrm{N}_{2} \mathrm{O}$ decomposition over $\mathrm{Fe} /$ zeolites-C/HT samples.

\begin{tabular}{lccc}
\hline Catalyst & $\begin{array}{c}\mathrm{N}_{2} \mathrm{O} \text { decomposition } \\
\text { [active Fe sites] } \\
\left(10^{19} / \mathrm{g}\right)\end{array}$ & $\begin{array}{c}R\left(\mathrm{~N}_{2} \mathrm{O}\right)^{\mathrm{a}} / \\
(\mathrm{mmol} /(\mathrm{g} \cdot \mathrm{h}))\end{array}$ & $\begin{array}{c}R\left(\mathrm{~N}_{2} \mathrm{O}\right)^{\mathrm{b}} / \\
(\mathrm{mmol} /(\mathrm{g} \cdot \mathrm{h}))\end{array}$ \\
\hline $\mathrm{Fe} /$ mordenite & 0.9 & 0.7 & $1.1^{\mathrm{b}}$ \\
$\mathrm{Fe} /$ ZSM-5 & 7.3 & 10.4 & $15.0^{\mathrm{b}}$ \\
$\mathrm{Fe} / \mathrm{beta}$ & 10.0 & 6.6 & $17.6^{\mathrm{b}}$ \\
Fe/ZSM-35 & 11.6 & 15.4 & $19.1^{\mathrm{c}}$ \\
\hline
\end{tabular}

a Rate of $\mathrm{N}_{2} \mathrm{O}$ decomposition at $733 \mathrm{~K}$ for $\mathrm{Fe} /$ zeolites-C samples.

b Rate of $\mathrm{N}_{2} \mathrm{O}$ decomposition at $713 \mathrm{~K}$ for Fe/mordenite-HT, Fe/beta-HT, and Fe/ZSM-5-HT samples.

${ }^{c}$ Rate of $\mathrm{N}_{2} \mathrm{O}$ decomposition at $673 \mathrm{~K}$ for Fe/ZSM-35-HT sample.

extra-framework $\mathrm{Al}$ in Fe/ZSM-35-HT, Fe/ZSM-5-HT, and $\mathrm{Fe} /$ beta-HT samples are the active sites in $\mathrm{N}_{2} \mathrm{O}$ decomposition. Only a very small amount of $\mathrm{N}_{2}$ was released in the transient response experiments, suggesting that almost no binuclear $\mathrm{Fe}$ sites are formed in the $\mathrm{Fe} /$ mordenite-HT sample.

\subsection{Catalytic activities of $\mathrm{Fe} /$ zeolites in $\mathrm{N}_{2} \mathrm{O}$ decomposition}

Figure 6(a) shows the $\mathrm{N}_{2} \mathrm{O}$ conversion versus temperature curves in $\mathrm{N}_{2} \mathrm{O}$ decomposition for the $\mathrm{Fe}$ /zeolites- $\mathrm{C}$ catalysts. For the Fe/ZSM-35-C, Fe/ZSM-5-C, and Fe/beta-C catalysts, $\mathrm{N}_{2} \mathrm{O}$ conversion starts at $700 \mathrm{~K}$ and is complete at about $773 \mathrm{~K}$. For the $\mathrm{Fe} /$ mordenite- $\mathrm{C}$ catalyst, the reaction takes place at 743 $\mathrm{K}$ and finishes at $853 \mathrm{~K}$. The rates of $\mathrm{N}_{2} \mathrm{O}$ decomposition at 733 $\mathrm{K}$ for the Fe/zeolites- $\mathrm{C}$ catalysts are in the order Fe/ZSM-35-C > Fe/ZSM-5-C > Fe/beta-C > Fe/mordenite-C (Table 2). Clearly, the rate of $\mathrm{N}_{2} \mathrm{O}$ decomposition increases linearly with the total quantity of isolated and oligonuclear Fe species (Fig. 7(a)), indicating that various types of $\mathrm{Fe}$ species, except large iron oxide nanoparticles, contribute to direct $\mathrm{N}_{2} \mathrm{O}$ decomposition.

The catalytic activities of all the Fe/zeolites catalysts in $\mathrm{N}_{2} \mathrm{O}$ decomposition increased significantly upon high-temperature treatment. The required temperature for $50 \% \mathrm{~N}_{2} \mathrm{O}$ conversion over the Fe/zeolites-HT samples was reduced by $80 \mathrm{~K}$ for Fe/ZSM-35-HT, $50 \mathrm{~K}$ for Fe/beta-HT, $40 \mathrm{~K}$ for Fe/ZSM-5-HT,

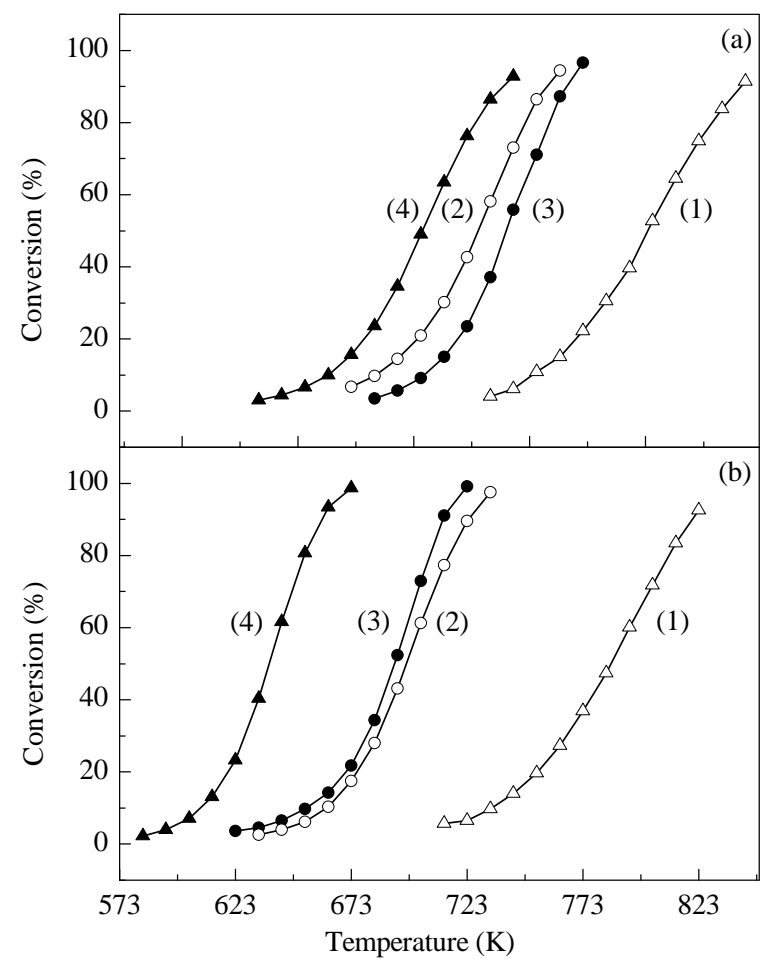

Fig. 6. $\mathrm{N}_{2} \mathrm{O}$ conversion versus temperature over Fe/zeolites- $\mathrm{C}$ (a) and $\mathrm{Fe} /$ zeolites-HT (b) samples. (1) Fe/mordenite; (2) Fe/ZSM-5; (3) Fe/beta; (4) Fe/ZSM-35. Reaction conditions: $5.0 \% \mathrm{~N}_{2} \mathrm{O} / \mathrm{He}$.

and $30 \mathrm{~K}$ for $\mathrm{Fe} /$ mordenite-HT compared with their corresponding calcined counterparts (Fig. 6). The $\mathrm{N}_{2} \mathrm{O}$ conversions at $713 \mathrm{~K}$ for the Fe/zeolites-HT catalysts are in the order $\mathrm{Fe} / \mathrm{ZSM}-35$-HT $>$ Fe/beta-HT $>$ Fe/ZSM-5-HT > $\mathrm{Fe} /$ mordenite-HT. Moreover, the rate of $\mathrm{N}_{2} \mathrm{O}$ decomposition at $713 \mathrm{~K}$ for the $\mathrm{Fe} /$ zeolites-HT catalysts is directly proportional to the concentration of active binuclear Fe sites, suggesting that the active binuclear $\mathrm{Fe}$ sites bound to extra-framework $\mathrm{Al}$ are responsible for direct $\mathrm{N}_{2} \mathrm{O}$ decomposition (Fig. 7(b)). The catalytic properties of the $\mathrm{Fe} /$ mordenite- $\mathrm{C}$ and $\mathrm{Fe} /$ mordenite-HT catalysts in $\mathrm{N}_{2} \mathrm{O}$ decomposition are very similar, indicating a low concentration of active binuclear Fe sites.
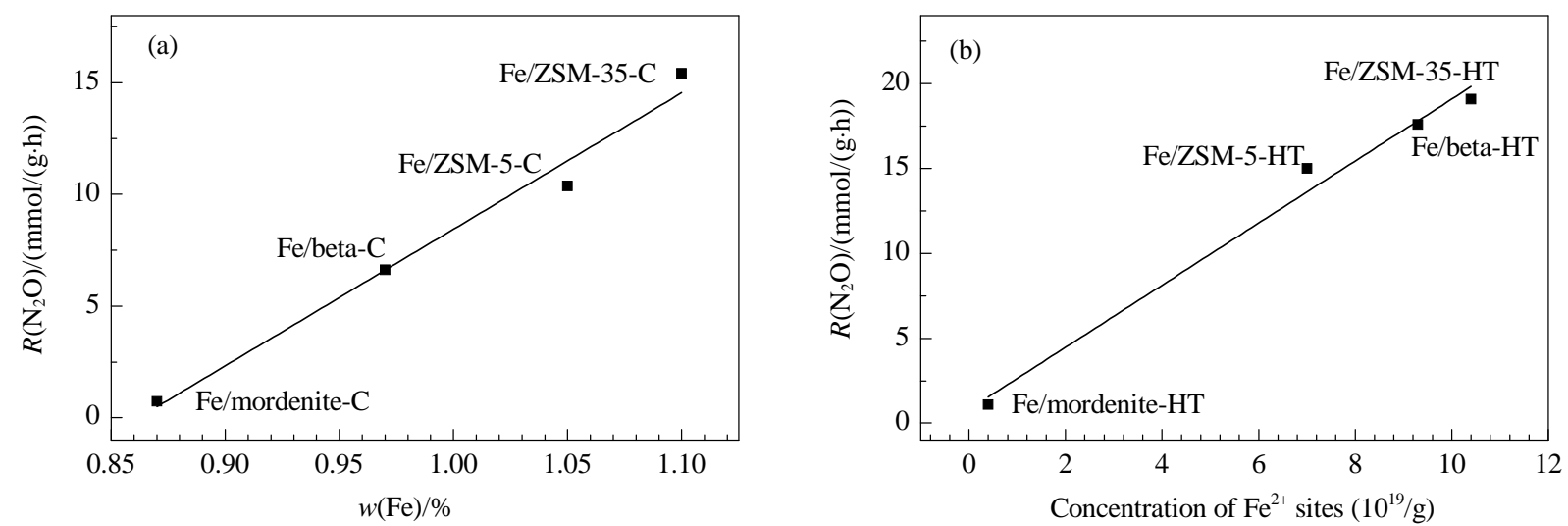

Fig. 7. (a) Dependence of the rate of $\mathrm{N}_{2} \mathrm{O}$ decomposition at $733 \mathrm{~K}$ on the total amount of isolated iron ions, bi-nuclear, and oligo-nuclear iron clusters estimated from the UV-Vis diffuse reflectance spectra of Fe/zeolites-C samples; (b) Dependence of the rate of $\mathrm{N}_{2} \mathrm{O}$ decomposition at $713 \mathrm{~K}$ on the concentration of $\mathrm{Fe}(\mathrm{II})$ sites determined by the transient response method for Fe/zeolites-HT samples. For the Fe/ZSM-35-HT sample, the rate of $\mathrm{N}_{2} \mathrm{O}$ decomposition was calculated at $673 \mathrm{~K}$. 


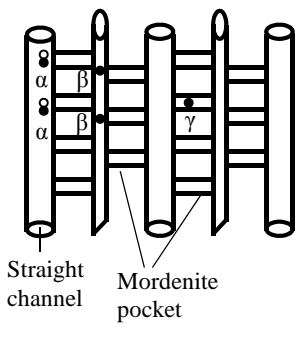

Mordenite
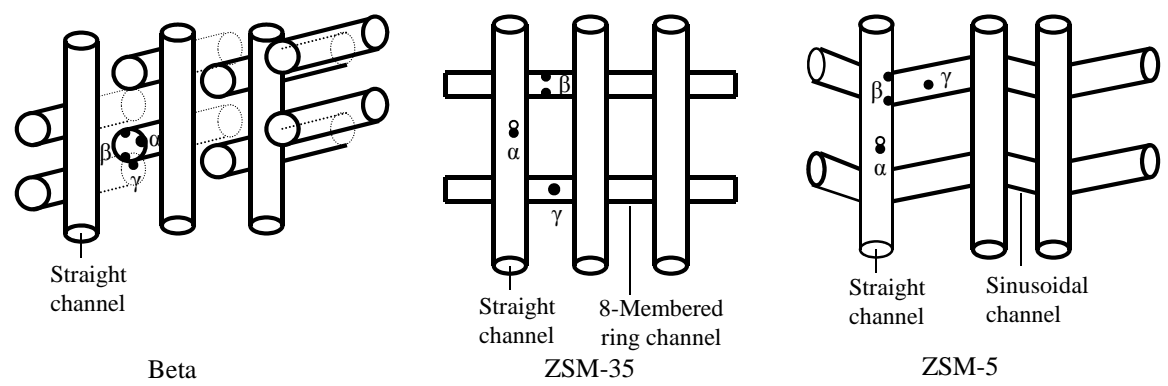

Fig. 8. The $\alpha-, \beta-$, and $\gamma$-type cationic sites in mordenite, beta, ZSM-35, and ZSM-5 zeolites.

The differences among the catalytic activities of the Fe/zeolites-HT samples are associated with differences in the concentrations of active binuclear Fe sites. Furthermore, the formation of active binuclear Fe sites correlates well with the zeolite framework type. For Fe/zeolites catalysts prepared using an ion-exchange method, three main cationic positions, $\alpha$, $\beta$, and $\gamma$, are populated by divalent cations in high-silica zeolites [9]. Figure 8 displays the $\alpha$-, $\beta$-, and $\gamma$-type cationic sites in FER, MFI, BEA, and MOR structures. The $\alpha$-type site is a six-membered ring composed of two five-membered rings (5-MR) and located in the main channels of the MOR, FER, and MFI frameworks or in the cages of polymorph $\mathrm{C}$ of the BEA framework. The $\beta$-type site is a twisted eight-membered ring (8-MR) in the MOR cavity, or a deformed six-membered ring (6-MR) located in the FER cavity, whereas in the ZSM-5 and beta zeolites, the $\beta$-type site is related to a deformed six-membered ring at the intersection of the straight and sinusoidal channels of ZSM-5 or inside the cages of polymorphs A and $\mathrm{B}$ of beta zeolite. The $\gamma$-type site corresponds to a boat-shaped site in the FER, MFI, and MOR frameworks, or a position inside the cages of polymorphs $\mathrm{A}$ and $\mathrm{B}$ of the beta zeolite.

The different frameworks have an impact on the accessibility of Co(II) ions located in the individual sites of zeolites. Dědeček et al. [50,51] reported that only Co(II) cations accommodated in the $\alpha$ and $\beta$ sites of zeolites are accessible to reactants and can play a role as reaction centers, whereas $\gamma$-type $\mathrm{Co}(\mathrm{II})$ cations are not accessible to reactants in Co/zeolite samples. Moreover, it is generally accepted that $\mathrm{O}_{2}$ desorption is the rate-determining step for $\mathrm{N}_{2} \mathrm{O}$ decomposition [25]. Short distances between the active Fe sites might therefore increase the probability of combination and desorption of adsorbed oxygen atoms. The distances between the two closest cationic sites represent the distances between the two closest cations. Different zeolite structures result in different distances of the two Fe(II) cations accommodated in two adjacent collaborating $\alpha$ or $\beta$ sites in ZSM-35, beta, ZSM-5, and mordenite. The distances between the neighboring $\alpha$ and $\beta$ sites in FER are 0.54 and 0.61 $\mathrm{nm}$, respectively, and those between two adjacent $\beta$ sites in beta, ZSM-5, and mordenite are $0.75,0.45$, and $0.7 \mathrm{~nm}$, respectively [50]. The distance between two neighboring $\alpha$ sites in ZSM-5 is $0.75 \mathrm{~nm}$, but the sites do not face each other, indicating that they are possibly not favorable for $\mathrm{N}_{2} \mathrm{O}$ decomposition. The distance between two neighboring $\beta$ sites is $0.75 \mathrm{~nm}$, and their appropriate arrangement is beneficial for the formation of the transition state in $\mathrm{N}_{2} \mathrm{O}$ decomposition $[8,10]$. Two adjacent collaborating $\alpha$ or $\beta$ sites in the main channel of the ZSM-35 zeolite, two neighboring $\beta$ sites inside the cages of polymorphs A and B of the beta zeolite, and two $\beta$ sites at the intersection of the straight and sinusoidal channels of the ZSM-5 structure are therefore appropriate for the formation of active binuclear Fe sites favorable for $\mathrm{N}_{2} \mathrm{O}$ decomposition.

Other important parameters controlling the formation of active $\mathrm{Fe}$ sites are the distributions and concentrations of $\mathrm{Al}$ pairs in specific cationic sites of high-silica zeolites; these have been shown to control the structures and concentrations of $\mathrm{Fe}$ ions in these zeolites [10,52]. The formation of binuclear Fe sites requires the presence of two $\mathrm{Al}$ atoms in each of the two cooperating cationic sites. The upper limit of the probability of the presence of an $\mathrm{Al}$ pair in each ring of the specific cationic sites can be estimated using bare $\operatorname{Co}(\mathrm{II})$ ions as a probe, analyzed by UV-visible diffuse reflectance absorbance spectroscopy [15-19].

Sklenak et al. [10] showed that the maximum loading of bare $\mathrm{Co}(\mathrm{II})$ ions is $\mathrm{Co} / \mathrm{Al}=0.31$ in ZSM-35 zeolite. Thus, $62 \%$ of all framework $\mathrm{Al}$ atoms are accommodated as pairs in the six-membered rings of $\alpha$ and $\beta$ sites. The Si/Al ratio of the ZSM-35 sample is 10.5 , meaning that the concentration of $\mathrm{Al}$ atoms is $7.9 \times 10^{-4} \mathrm{~mol} / \mathrm{g}$. The $\mathrm{Fe}$ exchange at $\mathrm{Fe} / \mathrm{Al}=0.33$ corresponds to $4.9 \times 10^{-4} \mathrm{~mol}$ of $\mathrm{Al}$ atoms per gram of $\mathrm{Fe} / \mathrm{ZSM}-35$ sample $\left(7.9 \times 10^{-4} \times 0.62\right)$. According to the literature, about $5 \%$ and $85 \%$ of Fe(II) cations are located at $\alpha$ - and $\beta$-type cationic sites, respectively [18]. The concentration of Fe(II) ions located in two adjacent collaborating $\alpha$ and $\beta$ sites that are able to form binuclear Fe sites is therefore $2.5 \times 10^{-4} \mathrm{~mol} / \mathrm{g}$. The maximum $\mathrm{Co} / \mathrm{Al}$ ratio reached for $\mathrm{Co}(\mathrm{II})$ ions exchanged to beta $(\mathrm{Si} / \mathrm{Al}=13)$ was 0.45 , showing that $90 \%$ of framework $\mathrm{Al}$ atoms are located in 6-MR as Al pairs. Among these, 55\% of the $\mathrm{Co}(\mathrm{II})$ ions are located at $\beta$ sites [17]. The $\mathrm{Fe} / \mathrm{Al}$ ratio of 0.33 of the $\mathrm{Fe} /$ beta catalyst means that the concentration of $\mathrm{Al}$ pairs at $\beta$ sites is $3.2 \times 10^{-4} \mathrm{~mol} / \mathrm{g}$ and the concentration of binuclear Fe sites is $1.6 \times 10^{-4} \mathrm{~mol} / \mathrm{g}$. For the ZSM-5 sample investigated, the maximum $\mathrm{Co} / \mathrm{Al}$ ratio was 0.4 , suggesting that $80 \%$ of the framework $\mathrm{Al}$ atoms are distributed in 6-MR as $\mathrm{Al}-\mathrm{O}-\mathrm{Si}-\mathrm{O}-\mathrm{Al}$ pairs, of which 50\% occupy $\beta$-type cationic sites [53]. This indicates that $40 \%$ of the framework $\mathrm{Al}$ atoms are accommodated in the six-membered rings of cationic $\beta$ sites. The highest attainable loading of $\mathrm{Fe}(\mathrm{II})$ ions at cationic $\beta$ sites $(\mathrm{Fe} / \mathrm{Al}=0.33)$ in ZSM-5 $(\mathrm{Si} / \mathrm{Al}=12.5)$ is therefore $1.3 \times 10^{-4} \mathrm{~mol} / \mathrm{g}$. In summary, the concentrations of active binuclear Fe sites in the 
Fe/ZSM-35-HT, Fe/beta-HT, and Fe/ZSM-5-HT samples are in the order Fe/ZSM-35-HT > Fe/beta-HT > Fe/ZSM-5-HT. This is in agreement with the catalytic performance of the $\mathrm{Fe}$ /zeolites-HT samples in direct $\mathrm{N}_{2} \mathrm{O}$ decomposition.

\section{Conclusions}

The effect of zeolite structure on the catalytic performance of $\mathrm{Fe}$ /zeolites-HT samples in $\mathrm{N}_{2} \mathrm{O}$ decomposition was investigated using UV-visible diffuse reflectance, in-situ FT-IR, and in-situ visible Raman spectroscopic techniques in combination with a transient response method. The catalytic activities of the $\mathrm{Fe} /$ zeolites-HT samples were in the order Fe/ZSM-35-HT > $\mathrm{Fe} /$ beta-HT $>\mathrm{Fe} / \mathrm{ZSM}-5$-HT $>\mathrm{Fe} /$ mordenite-HT. A good relationship was found between the rate of $\mathrm{N}_{2} \mathrm{O}$ decomposition and the concentration of binuclear Fe sites, indicating that the binuclear Fe sites are the active sites for $\mathrm{N}_{2} \mathrm{O}$ decomposition. It was shown that two Fe(II) cations located in two adjacent collaborating six-membered rings in a 10-membered ring channel $(\alpha$ sites) or in two adjacent six-membered rings in an eight-membered ring channel ( $\beta$ sites) in the ZSM-35 framework can form active binuclear iron sites. Similar structures can also be formed in two adjacent six-membered rings in polymorphs A and B of the beta zeolite or in two neighboring six-membered rings at the intersection of straight and sinusoidal channels of the ZSM-5 zeolite.

\section{References}

[1] Pérez-Ramírez J, Kapteijn F, Schöffel K, Moulijn J A. Appl Catal B, 2003, 44: 117

[2] Pérez-Ramírez J, Kapteijn F, Mul G, Xu X, Moulijn J A. Catal Today, 2002, 76: 55

[3] Parmon V N, Panov G I, Uriarte A, Noskov A S. Catal Today, 2005, 100: 115

[4] Hansen N, Heyden A, Bell A T, Keil F J. J Catal, 2007, 248: 213

[5] Pirngruber G D, Roy P K, Prins R. J Catal, 2007, 246: 147

[6] Roy P K, Prins R, Pirngruber G D. Appl Catal B, 2008, 80: 226

[7] Øygarden A H, Pérez-Ramírez J. Appl Catal B, 2006, 65: 163

[8] Kaucký D, Sobalík Z, Schwarze M, Vondrová A, Wichterlová B. J
Catal, 2006, 238: 293

[9] Jiša K, Nováková J, Schwarze M, Vondrová A, Sklenák S, Sobalik Z.J Catal, 2009, 262: 27

[10] Sklenák S, Andrikopoulos P C, Boekfa B, Jansang B, Nováková J, Benco L, Bucko T, Hafner J, Dědeček J, Sobalík Z. J Catal, 2010, 272 : 262

[11] Pantu P, Boekfa B, Sunpetch B, Limtrakul J. Chem Eng Commun, 2008, 195: 1477

[12] Pérez-Ramírez J, Groen J C, Brückner A, Kumar M S, Bentrup U, Debbagh M N, Villaescusa L A.J Catal, 2005, 232: 318

[13] Melián-Cabrera I, Mentruit C, Pieterse J A Z, van den Brink R W, Mul G, Kapteijn F, Moulijn J A. Catal Commun, 2005, 6: 301

[14] Xia H A, Sun K Q, Fan F T, Sun K J, Su W G, Feng Zh Ch, Ying P L, Li C. J Catal, 2008, 259: 269

[15] Dědeček J, Kaucký D, Wichterlová B. Microporous Mesoporous Mater, 2000, 35-36: 483

[16] Sobalík Z, Dědeček J, Kaucký D, Wichterlová B, Drozdová L, Prins R. J Catal, 2000, 194: 330

[17] Dědeček J, Čapek L, Kaucký D, Sobalík Z, Wichterlová B. J Catal, 2002, 211: 198

[18] Drozdová L, Prins R, Dědeček J, Sobalík Z, Wichterlová B. J Phys Chem B, 2002, 106: 2240

[19] Dědeček J, Wichterlová B. J Phys Chem B, 1999, 103: 1462

[20] Attfield M P, Weigel S J, Cheetham A K. J Catal, 1997, 170: 227

[21] Dalconi M C, Cruciani G, Alberti A, Ciambelli P, Rapacciuolo M T. Microporous Mesoporous Mater, 2000, 39: 423

[22] Sun K Q, Xia H A, Feng Zh Ch, van Santen R, Hensen E J M, Li C. J Catal, 2008, 254: 383

[23] Wang J Y, Li G N, Ju X H, Xia H A, Fan F T, Wang J H, Feng Zh Ch, Li C. J Catal, 2013, 301: 77

[24] Kumar M S, Schwidder M, Grünert W, Brückner A. J Catal, 2004, 227: 384

[25] Pérez-Ramírez J.J Catal, 2004, 227: 512

[26] Pérez-Ramírez J, Kumar M S, Brückner A.J Catal, 2004, 223: 13

[27] Pérez-Ramírez J, Mul G, Kapteijn F, Moulijn J A, Overweg A R, Doménech A, Ribera A, Arends I W C E. J Catal, 2002, 207: 113

[28] Bordiga S, Buzzoni R, Geobaldo F, Lamberti C, Giamello E, Zecchina A, Leofanti G, Petrini G, Tozzola G, Vlaic G. J Catal, 1996, 158: 486

[29] Hadjiivanov K, Ivanova E, Kefirov R, Janas J, Plesniar A, Dzwigaj S, Che M. Microporous Mesoporous Mater, 2010, 131: 1

[30] Hensen E J M, Zhu Q, van Santen R A. J Catal, 2003, 220: 260

[31] Long J L, Zhang Z Zh, Ding Zh X, Ruan R Sh, Li Zh H, Wang X X. J

\section{Graphical Abstract}

Chin. J. Catal., 2013, 34: 876-888 doi: 10.1016/S1872-2067(12)60555-5

\section{Catalytic performance of different types of iron zeolites in $\mathrm{N}_{2} \mathrm{O}$ decomposition}

WANG Junying, XIA Haian, JU Xiaohua, FAN Fengtao, FENG Zhaochi, LI Can* Dalian Institute of Chemical Physics, Chinese Academy of Sciences; Graduate University of Chinese Academy of Sciences

The influence of zeolite frameworks on the catalytic properties of $\mathrm{Fe}$ /zeolites in $\mathrm{N}_{2} \mathrm{O}$ decomposition was investigated using a combination of UV-Vis diffuse reflectance, in-situ FT-IR, and in-situ visible Raman spectroscopic techniques with a transient response method.

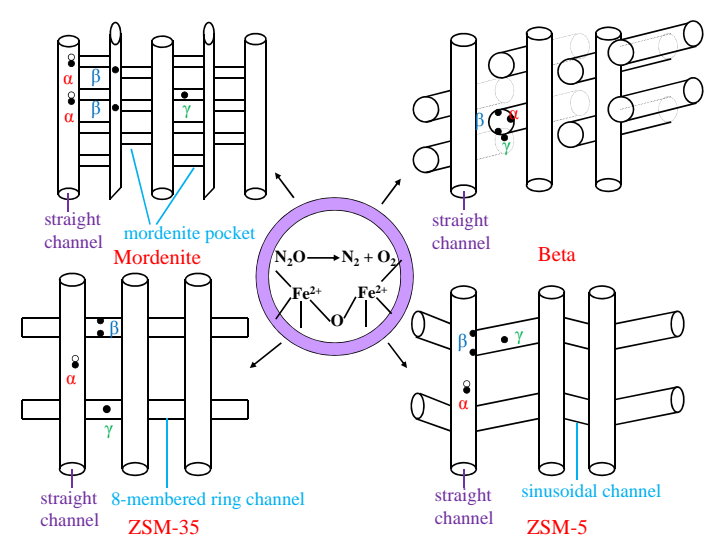


Phys Chem C, 2010, 114: 15713

[32] Lobree L J, Hwang I-C, Reimer J A, Bell A T. Catal Lett, 1999, 63: 233

[33] Yuranov I, Bulushev D A, Renken A, Kiwi-Minsker L. Appl Catal A, 2007, 319: 128

[34] Xia H A, Sun K Q, Sun K J, Feng Zh Ch, Li W X, Li C.J Phys Chem C, 2008, 112: 9001

[35] Li C, Xiong G, Xin Q, Liu J K, Ying P L, Feng Zh Ch, Li J, Yang W B, Wang Y Zh, Wang G R, Liu X Y, Lin M, Wang X Q, Min E Z. Angew Chem, Int Ed, 1999, 38: 2220

[36] Fan F T, Xu Q, Xia H A, Sun K J, Feng Zh Ch, Li C. Chin J Catal (范峰 滔, 徐倩, 夏海岸, 孙科举, 冯兆池, 李灿. 催化学报), 2009, 30: 717

[37] Nosheen S, Galasso F, Suib S L. Sci Adv Mater, 2009, 1: 31

[38] Twu J, Dutta P K, Kresge C T. J Phys Chem, 1991, 95: 5267

[39] Dutta P K, Rao K M, Park J Y.J Phys Chem, 1991, 95: 6654

[40] Fan F T, Feng Zh Ch, Li C. Acc Chem Res, 2010, 43: 378

[41] Yu Y, Xiong G, Li C, Xiao F-Sh. Microporous Mesoporous Mater, 2001, 46: 23

[42] de Faria D L A, Venaüncio Silva S, de Oliveira M T. J Raman Spectrosc, 1997, 28: 873
[43] Tosheva L, Mihailova B, Valtchev V, Sterte J. Microporous Mesoporous Mater, 2001, 48: 31

[44] Lewandowska A E, Banares M A, Tielens F, Che M, Dzwigaj S. J Phys Chem C, 2010, 114: 19771

[45] Dutta P K, Rao K M, Park J Y. Langmuir, 1992, 8: 722

[46] Suzuki Y, Wakihara T, Itabashi K, Ogura M, Okubo T. Top Catal, 2009, 52: 67

[47] Mihailova B, Valtchev V, Mintova S, Faust A-C, Petkov N, Bein T. Phys Chem Chem Phys, 2005, 7: 2756

[48] Majano G, Mintova S, Ovsitser O, Mihailova B, Bein T. Microporous Mesoporous Mater, 2005, 80: 227

[49] Fan F T, Sun K J, Feng Zh Ch, Xia H A, Han B, Lian Y X, Ying P L, Li C. Chem Eur J, 2009, 15: 3268

[50] Dědecěk J, Kaucký D, Wichterlová B. Top Catal, 2002, 18: 283

[51] Kaucký D, Vondrová A, Dědecěk J, Wichterlová B. J Catal, 2000, 194: 318

[52] Kapteijn F, Rodriguez-Mirasol J, Moulijn J A. Appl Catal B, 1996, 9: 25

[53] Dědecĕk J, Kaucký D, Wichterlová B, Gonsiorová O. Phys Chem Chem Phys, 2002, 4: 5406

\title{
不同类型含铁分子篮上 $\mathrm{N}_{2} \mathrm{O}$ 催化分解反应
}

\author{
王俊英 ${ }^{\mathrm{a}, \mathrm{b}}$, 夏海岸 ${ }^{\mathrm{a}}$, 鞠晓花 ${ }^{\mathrm{a}}$, 范峰滔 ${ }^{\mathrm{a}}$, 冯兆池 ${ }^{\mathrm{a}}$, 李 灿 $^{\mathrm{a},{ }^{*}}$ \\ a中国科学院大连化学物理研究所催化基础国家重点实验室, 辽宁大连 116023 \\ $\mathrm{b}$ 中国科学院大学, 北京100049
}

摘要: 采用固态离子交换法制备了一系列 $\mathrm{Fe} / \mathrm{Al}$ 摩尔比为 0.33 的 $\mathrm{Fe} /$ 分子笁 $(\mathrm{ZSM}-35, \mathrm{ZSM}-5$, beta和mordenite (丝光沸石))样品, 并 利用紫外-可见漫反射光谱、原位红外光谱和可见拉曼光谱以及瞬态应答实验考察了分子笁种类对 $\mathrm{N}_{2} \mathrm{O}$ 分解反应性能的影响. 研 究表明, 经高温处理(HT)后分子笁的催化活性顺序为 Fe/ZSM-35 > Fe/beta > Fe/ZSM-5 > Fe/mordenite, 与骨架外铝稳定的双核铁 物种含量一致. 这说明双核铁物种是高温处理后 $\mathrm{Fe} /$ 分子篎样品中 $\mathrm{N}_{2} \mathrm{O}$ 分解的活性位, 而它的形成与分子笁种类密切相关. Fe/ZSM-35分子篎十元环孔道中相邻两个 $\alpha$ 位和八元环孔道中相邻两个 $\beta$ 位都能稳定两个 $\mathrm{Fe}(\mathrm{II})$ 离子而形成能高效分解 $\mathrm{N}_{2} \mathrm{O}$ 的双核 铁活性中心. Fe/beta和Fe/ZSM-5分子篮中只有落在相邻两个 $\beta$ 位上的两个 $\mathrm{Fe}(\mathrm{II})$ 离子才能形成参与 $\mathrm{N}_{2} \mathrm{O}$ 分解的高活性的双铁活性 中心. Fe/mordenite-HT分子篮上的铁物种绝大部分以孤立Fe离子的形式存在, 因此其催化 $\mathrm{N}_{2} \mathrm{O}$ 分解反应活性很低.

关键词: 铁; 分子篮; 氧化亚氮分解; 拉曼光谱

收稿日期: 2012-12-26. 接受日期: 2013-02-24. 出版日期: 2013-05-20.

*通讯联系人. 电话: (0411)84379070; 传真: (0411)84694447; 电子信箱: canli@dicp.ac.cn

基金来源：国家自然科学基金(21173213); 国家重点基础研究发展计划(973计划, 2009CB623507).

本文的英文电子版由Elsevier出版社在ScienceDirect上出版(http://www.sciencedirect.com/science/journal/18722067).

\section{1. 前言}

含铁分子篮是一种优良的 $\mathrm{N}_{2} \mathrm{O}$ 分解消除催化剂, 能 将温室气体 $\mathrm{N}_{2} \mathrm{O}$ 有效分解成 $\mathrm{N}_{2}$ 和 $\mathrm{O}_{2}{ }^{[1,2]}$. Panov 课题 组 ${ }^{[3 \sim 6]}$ 发现, Fe/ZSM-5在 $\mathrm{N}_{2} \mathrm{O}$ 分解反应中表现出独特而 优异的催化性能. 然而, 到目前为止大部分有关含铁分 子篮的工作都集中在 Fe/ZSM-5体系上; 实验和理论的 研究主要集中在催化剂的制备和预处理条件对 $\mathrm{Fe} / \mathrm{ZSM}-5$ 活性位结构和性质的影响、 $\mathrm{N}_{2} \mathrm{O}$ 消除反应的机 理以及催化剂的实际应用等方面 ${ }^{[3 \sim 6]}$. 有关不同的含铁

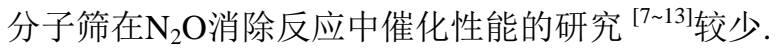

Øygarden等 ${ }^{[7]}$ 研究了含有 $1 \times 10^{-6}$ 级铁物种的商品 化的BEA, FER 和MFI分子篮在 $\mathrm{N}_{2} \mathrm{O}$ 消除反应中的催化 性能, 发现高温水蒸气处理后的BEA分子篮表现出最高 的催化活性. 这可能是由于在高温水蒸气处理过程中, BEA分子耖骨架中的铁和铝更容易脱出骨架, 形成了骨 架外铝稳定的双核或低聚的铁活性位造成的. Kaucký 等 ${ }^{[8]}$ 研究发现, 由于 Fe/ferrierite中 Fe-Fe之间的距离较 短, 因而在 $\mathrm{N}_{2} \mathrm{O}$ 消除反应中的催化性能比铁含量相似的 $\mathrm{Fe} / \mathrm{beta}$ 更优异. Jíša 等 ${ }^{[9,10]}$ 通过实验与理论计算相结合的 方式研究发现, 在Fe/ferrierite分子耖中存在一种特殊结 构的铁活性位, 即八元环孔道中相邻两个六元环中的两 
个 $\mathrm{Fe}(\mathrm{II})$ 离子, 从而使 Fe/ferrierite分子篮在 $\mathrm{N}_{2} \mathrm{O}$ 消除反应 中表现出比Fe/ZSM-5和Fe/beta分子篎更优异的催化性 能. Pantu等 ${ }^{[11]}$ 研究发现, 在Fe/FER, Fe/BEA, Fe/ZSM-5 和 $\mathrm{Fe} / \mathrm{FAU}$ 四种分子篮中, 由于 $\mathrm{Fe} / \mathrm{FER}$ 具有较小的孔道 和较强的吸附 $\mathrm{N}_{2} \mathrm{O}$ 的能力, 因而在 $\mathrm{N}_{2} \mathrm{O}$ 消除反应中的催 化活性最高. Pérez-Ramírez 等 ${ }^{[12]}$ 比较了 $\mathrm{Fe} / \mathrm{MFI}$ 与 $\mathrm{Fe} / \mathrm{BEA}$ 在 $\mathrm{N}_{2} \mathrm{O}$ 消除反应中的催化性能, 认为不同的催化 剂中存在结构类似的铁物种, 不同的微孔分子篮载体对 催化剂的催化性能没有影响. Melián-Cabrera等 ${ }^{[13]}$ 报道 了 $\mathrm{Fe} / \mathrm{FER}$ 在模拟硝酸工厂尾气条件下的 $\mathrm{N}_{2} \mathrm{O}$ 消除反应 中具有比 $\mathrm{Fe} / \mathrm{MFI}$ 和 Fe/BEA更优越的催化性能. 这可能 是由于FER分子篮更有利于铁活性位的形成和稳定. 然 而, 分子篮种类与含铁分子篮催化 $\mathrm{N}_{2} \mathrm{O}$ 消除反应性能的 关系尚不清楚.

研究认为, 不同的Fe/zeolites中, 骨架外孤立的铁阳 离子、双核或低聚的铁物种、低聚的Fe-O-Al混合氧化 物和分子篮外表面上较大的氧化铁纳米颗粒都可能是 $\mathrm{N}_{2} \mathrm{O}$ 消除反应的活性中心 ${ }^{[14]}$. 活性中心的结构与 Fe/zeolites样品的制备方法、预处理条件以及铁物种在 分子篮中的落位和配位环境密切相关. Wichterlová课题 组 ${ }^{[15 ~ 19]}$ 采用 $\mathrm{Co}$ (II) 离子为探针, 利用红外光谱(FT-IR)和 紫外-可见漫反射(UV-Vis) 光谱等研究发现, 在高硅的 pentasil型分子篮(FER, MFI, BEA和MOR)中, Co(II)离子 主要占据三种类型的阳离子位: $\alpha, \beta$ 和 $\gamma$ 位. Attfield等 ${ }^{[20]}$ 和Dalconi等 ${ }^{[21]}$ 分别利用单晶X射线衍射(XRD)和同步 辐射的XRD技术研究了 Cu-mordenite和Ni-ferrierite分子 篮中Cu(II)离子和 $\mathrm{Ni}(\mathrm{II})$ 离子的落位. 他们发现, $\mathrm{Cu}(\mathrm{II})$ 离 子主要落在mordenite分子筛的 $\alpha$ 位上, $\mathrm{Ni}(\mathrm{II})$ 离子主要落 在ferrierite分子篮的 $\beta$ 位上. 由此可知, 二价的过渡金属 阳离子在pentasil型分子篎中的落位规律具有普适性.

近年来, 李灿课题组 ${ }^{[22,23]}$ 对含铁分子篮, 特别是 $\mathrm{Fe} / \mathrm{ZSM}-5$ 和Fe/ZSM-35 在 $\mathrm{N}_{2} \mathrm{O}$ 分解反应中的活性中心进 行了深入的研究, 发现双核铁位是 $\mathrm{N}_{2} \mathrm{O}$ 分解的活性中心. 本文综合运用多种谱学技术研究了几种 Fe/zeolites (FER, MFI, BEA和MOR) 在 $\mathrm{N}_{2} \mathrm{O}$ 分解反应中的催化性能 与分子笁结构的关系.

\section{2. 实验部分}

\section{1. 催化剂的制备}

采用固态离子交换法制备一系列Fe改性的ZSM-35, beta, ZSM-5和mordenite (丝光沸石)负载型催化剂, Fe/Al 摩尔比为 0.33 . 典型的制备过程如下. 首先将 $2 \mathrm{~g}$
$\mathrm{NH}_{4}{ }^{+}$/zeolite在823 K 下 ${ }_{2}$ 中焙烧 $2 \mathrm{~h}$, 接着将样品冷却到 室温, 密封, 放入手套箱中. 在手套箱中, H/zeolite与适 量的无水 $\mathrm{FeCl}_{3}$ (Sigma-Aldrich, AR)混合研磨. 研磨后的 混合物重新放回反应器中, 再次将反应器密封, 取出手 套箱. 在 $\mathrm{He}$ 气氛中, 样品的温度从室温升到 $598 \mathrm{~K}$, 保持 2 h. 温度降至 $498 \mathrm{~K}$ 后, 在 $0.5 \% \mathrm{H}_{2} \mathrm{O} / \mathrm{He}$ 气氛中水解除去 $\mathrm{Fe}-\mathrm{Cl}$ 键. 反应完成后, 将产物在 $823 \mathrm{~K}^{\mathrm{K}} \mathrm{O}_{2}$ 中焙烧 $2 \mathrm{~h}$, 得到 $\mathrm{Fe}$ /zeolite-C样品, $\mathrm{C}$ 代表在 $823 \mathrm{~K}$ 下 $\mathrm{O}_{2}$ 中焙烧(以下 简称焙烧). 一部分Fe/zeolite-C样品在 $1173 \mathrm{~K}$ 下He中处 理 $2 \mathrm{~h}$, 得到Fe/zeolite-HT样品, HT代表在1173 K下 He中 处理(以下简称高温处理). 所用四种分子篎载体分别是 $\mathrm{NH}_{4}{ }^{+} / \mathrm{ZSM}-35\left(\mathrm{SiO}_{2} / \mathrm{Al}_{2} \mathrm{O}_{3}=21\right.$, 自 制 $), \mathrm{NH}_{4}{ }^{+} / \mathrm{ZSM}-5$ $\left(\mathrm{SiO}_{2} / \mathrm{Al}_{2} \mathrm{O}_{3}=25\right), \mathrm{NH}_{4}{ }^{+} /$beta $\left(\mathrm{SiO}_{2} / \mathrm{Al}_{2} \mathrm{O}_{3}=26\right)$ 和 $\mathrm{NH}_{4}{ }^{+} /$ mordenite $\left(\mathrm{SiO}_{2} / \mathrm{Al}_{2} \mathrm{O}_{3}=23\right.$, 南开催化剂厂).

\section{2. 催化剂的表征}

样品化学组成由ICP-AES (电感耦合等离子体-原子 发射光谱)测定. XRD谱在日本Rigaku D/MAX 2500型X 射线衍射仪 $\left(40 \mathrm{kV}, 200 \mathrm{mV}, \mathrm{Cu} K_{\alpha}\right.$ 为射线源, 以 $0.02^{\circ}$ 间 隔阶梯扫描, 扫描速度 $5 \%$ min)上测定.

UV-Vis谱在室温下在JASCO V-550型紫外-可见光 谱仪上测定 (以 $\mathrm{BaSO}_{4}$ 作为参比样品). 将 $\mathrm{Fe} /$ zeolite-C样 品的紫外-可见漫反射光谱图用高斯函数作分峰拟合, 然后将各个拟合峰的相对强度与分子篎样品中的总铁 含量相乘即得到 Fe/zeolite-C样品中不同铁物种的含 量 ${ }^{[12]}$. 需要注意的是, 这种分析方法没有考虑各种铁物 种在不同波长的吸收系数的差异.

样品的FT-IR谱在Nicolet Impact 470型红外光谱仪 上采集. 采用液氮冷却的 MCT-B探测器, 分辨率为 4 $\mathrm{cm}^{-1}$, 扫描次数为 32 次, 光谱扫描范围为 $4000 \sim 650 \mathrm{~cm}^{-1}$. 具体过程如下. 将 $\mathrm{Fe} / \mathrm{zeolite}$ 样品压成自支撑片(约 10 $\mathrm{mg} / \mathrm{cm}^{2}$ ), 并放入以 $\mathrm{CaF}_{2}$ 为窗片的石英原位红外池中. Fe/zeolite-C样品在 $623 \mathrm{~K}$ 下 $\mathrm{O}_{2}$ 中处理 $1 \mathrm{~h}, \mathrm{Fe} /$ zeolite-HT 样品在 $623 \mathrm{~K}$ 下 $\mathrm{He}$ 中处理 $1 \mathrm{~h}$. 接着将样品在相同的气氛 中冷却到室温, 采集红外光谱作为相应样品的背景谱. 然后, 将原位处理的样品暴露在 $1.0 \% \mathrm{NO} / \mathrm{He}$ 气氛中, $\mathrm{NO}$ 吸附饱和后再用 $\mathrm{He}$ 吹扫 $10 \mathrm{~min}$, 气体的流速均为 60 $\mathrm{ml} / \mathrm{min}$. 每个样品的FT-IR谱峰强度用分子篮晶格振动 的泛频区的谱峰强度(1500 2000 $\mathrm{cm}^{-1}$ )作归一化.

样品的可见拉曼光谱在自主研制搭建的三光栅紫 外-可见拉曼光谱仪上采集. 采用固态激光器发射的532 $\mathrm{nm}$ 可见激光作光源. 首先将样品压成自支撑片, 放入石 英原位反应池中. 再将样品在 $1173 \mathrm{~K}$ 下 $\mathrm{He}$ 中处理 $1 \mathrm{~h}$. 
然后将样品冷却到 $523 \mathrm{~K}$, 在石英原位反应池中通入 $5.0 \% \mathrm{~N}_{2} \mathrm{O} / \mathrm{He}$ 混合气. 每次处理完成后, 将样品冷却到室 温采集拉曼谱.

采用瞬态应答方法测定铁活性物种的量. 首先将 Fe/zeolite-HT样品在1173 K下 He中处理 $1 \mathrm{~h}$, 然后冷却到 瞬态应答反应所需要的温度。再将气体换成 $5.0 \%$ $\mathrm{N}_{2} \mathrm{O} / \mathrm{He}$ 混合气. 样品中铁活性物种的量通过计算生成 $\mathrm{N}_{2}$ 的积分面积获得.

\section{3. 催化剂的评价}

$\mathrm{N}_{2} \mathrm{O}$ 分解反应在直径为 $4 \mathrm{~mm}$ 的U形石英反应器中进 行, 催化剂用量 $50 \mathrm{mg}$. 原料气组成 $5.0 \% \mathrm{~N}_{2} \mathrm{O}, \mathrm{He}$ 平衡气, GHSV 为 $24000 \mathrm{~h}^{-1}$. 尾气组成采用四级杆质谱仪 (Gam 200, Pfeiffer Vaccum)在线检测.

\section{3. 结果与讨论}

\section{1. $\mathrm{H}(\mathrm{Fe}) / \mathrm{zeolite}$ 的XRD谱}

图1(a)是 H/mordenite, H/beta, H/ZSM-35和H/ZSM-5 分子篮的XRD谱. 可以看出, 所用的H/zeolite载体有很 好的结晶度, 担载了 $\mathrm{Fe}$ 之后, 无论是 Fe/zeolite-C还是 Fe/zeolite-HT样品都只观察到分子篮骨架的特征衍射 峰, 且未观察到归属于氧化铁纳米颗粒的特征衍射峰 (见图1(b)和(c)), 表明这些样品中分子篎的骨架得到了 很好的保持, 并且Fe物种很好地分散于其上.

\subsection{Fe/zeolite样品的紫外-可见漫反射光谱}

采用UV-Vis 谱表征了 Fe/zeolite样品中各种铁物种 的配位环境. 图2(a)为Fe/zeolite-C样品的紫外-可见漫反 射光谱图. 由图可见, Fe/mordenite-C样品在 240,275 和 $360 \mathrm{~nm}$ 处出现吸收峰, 且在 $540 \mathrm{~nm}$ 有一个弱的肩峰; $\mathrm{Fe} / \mathrm{beta}-\mathrm{C}$ 和Fe/ZSM-5-C在 240 和 $360 \mathrm{~nm}$ 处出现明显的吸 收峰, 在540 nm出现一个弱的肩峰. 对于Fe/ZSM-35-C 而言, 240, 275, 360 和 $540 \mathrm{~nm}$ 处吸收峰的强度比其它三 种Fe/zeolite-C样品都要强. 图2(b) 是Fe/zeolite-HT样品 的紫外-可见漫反射光谱图. 可以看出, 高温处理后样品 于 $275 \mathrm{~nm}$ 处的吸收峰强度明显增大, 而 240,360 和 540 $\mathrm{nm}$ 处的吸收峰强度明显减弱。这表明高温处理使 $\mathrm{Fe} /$ zeolite样品上的铁物种结构发生了显著的变化.

研究表明, 200 300 nm处吸收峰与四配位或更高配 位的孤立铁物种的电荷转移跃迁有关 ${ }^{[24 ~ 27], 300 ~ 450 ~ n m ~}$ 处很宽的吸收峰归属于六配位或寡聚的铁物种, $450 \mathrm{~nm}$ 以上的吸收峰则来自小的氧化铁纳米颗粒 ${ }^{[28]}$. 因此, 240 和 $275 \mathrm{~nm}$ 处吸收峰分别与分子篎骨架中四配位的铁 物种和分子篮骨架外六配位铁物种的 $\mathrm{O} \rightarrow \mathrm{Fe}(\mathrm{III})$ 的电荷
转移跃迁有关; 360 和 $540 \mathrm{~nm}$ 处吸收峰则分别来自寡聚 的铁物种和体相的氧化铁纳米颗粒. 由此可见, 高温处 理后的样品中六配位的孤立铁物种明显增多, 同时寡聚 的铁物种和氧化铁纳米颗粒的量显著减少. 用紫外-可 见吸收光谱确定的不同铁物种的含量列于表1. 可以看 出, Fe/zeolite-C样品中铁物种主要以孤立和寡聚的形式 存在，它们的总含量大小顺序为 Fe/ZSM-35-C > Fe/ZSM-5-C > Fe/beta-C > Fe/mordenite-C. 这表明引入 的 $\mathrm{Fe}$ 物种主要是以高分散的形式负载在分子篮的孔道 中或外表面上.

\subsection{Fe/zeolite样品的FT-IR谱}

图 3(a) 和 (b) 分别为室温时 1.0\% NO 在 Fe/zeolite-C/HT样品上吸附饱和, 再经He吹扫后的原位 FT-IR谱. 由图可见, Fe/zeolite-C样品分别在1626, 1610 和1580 $\mathrm{cm}^{-1}$ 处出现吸收峰, 经 $1173 \mathrm{~K}$ 下 He中处理后, 除 1626 和 $1580 \mathrm{~cm}^{-1}$ 处吸收峰外, 还在 $1874 \mathrm{~cm}^{-1}$ 处出现了一 个新的吸收峰. 在Fe/ZSM-5-HT分子篮样品上还出现一 个位于 $1892 \mathrm{~cm}^{-1}$ 处的吸收峰. 1580,1610 和 $1626 \mathrm{~cm}^{-1}$ 处 吸收峰归属于铁氧化物上吸附的 $-\mathrm{NO}_{3}{ }^{-}$和/或 $-\mathrm{NO}_{2}{ }^{-}$基团 的吸收振动峰 ${ }^{[29 ~ 31]}$. 这可能是由于分子篮表面吸附的 $\mathrm{NO}$ 与反应气中残留的微量 $\mathrm{O}_{2}$ 或者分子篮表面的氧物种 发生反应, 生成吸附态的 $\mathrm{N}_{2} \mathrm{O}_{4}, \mathrm{NO}_{2}, \mathrm{NO}_{3}{ }^{-}$或 $\mathrm{NO}_{2}{ }^{-}$所致. 1874 和 $1892 \mathrm{~cm}^{-1}$ 处吸收峰则分别对应于骨架外 $\mathrm{Fe}-\mathrm{O}-\mathrm{Al}$ 物种 ${ }^{[22]}$ 和孤立或寡聚的铁物种上 $\mathrm{NO}$ 的吸收 振动峰 ${ }^{[32]}$. 这两个峰均对应于 $\mathrm{NO}$ 在 $\mathrm{Fe}(\mathrm{II})$ 离子而不是 $\mathrm{Fe}(\mathrm{III})$ 离子上的吸附 ${ }^{[33]}$. 综上可知, 高温处理过程中,骨 架脱铝和铁物种结构的改变使得位于铝阳离子位的价 键补偿铁离子转变成骨架外的Fe-O-Al混合氧化物, 后 者在 $\mathrm{N}_{2} \mathrm{O}$ 分解反应中起着重要的作用 ${ }^{[22]}$.

\subsection{Fe/zeolite样品的可见拉曼光谱}

李灿课题组 ${ }^{[23,34]}$ 的研究表明, 可见共振拉曼光谱可 以灵敏而高选择性地鉴定含铁分子篮中的活性氧物种, 比如 Fe/ZSM-5 分子篮 中 的 $\mathrm{Fe}_{2}\left(\mu-1,2-\mathrm{O}_{2}\right)$ 物 种和 $\mathrm{Fe} / \mathrm{ZSM}-35$ 分子篎中的 $\mathrm{Fe}_{2}(\mu-\mathrm{O})_{2}$ 物种. 共振拉曼效应是 指当采用的激光频率与待测分子的某个电子吸收峰接 近或重合时, 这一分子的某个或几个特征拉曼谱带强度 可以达到正常拉曼谱带的几倍甚至 $10^{4} \sim 10^{6}$ 倍 ${ }^{[35,36]}$. 与 正常拉曼光谱相比, 共振拉曼光谱在有特定吸收峰的低 浓度和微量样品的检测中发挥着重要作用. 图4(a)为 Fe/zeolite-HT 样品的可见拉曼光谱. 由图可见, $\mathrm{Fe} /$ mordenite-HT 分子篮于 $402,465,800$ 和 $830 \mathrm{~cm}^{-1}$ 处出 现四个特征峰, 均对应于 mordenite的骨架振动 [37 39]; 
Fe/beta-HT分子篮在 $320,410,470,613,700$ 和 $830 \mathrm{~cm}^{-1}$ 处 出现六个特征峰, 其中 320,410 和 $470 \mathrm{~cm}^{-1}$ 处特征峰分别 归属于六元环、五元环和四元环的呼吸振动 ${ }^{[40]} ; 830 \mathrm{~cm}^{-1}$ 处特征峰则来自分子篮骨架中 $\mathrm{Si}-\mathrm{O}$ 的伸缩振动 ${ }^{[41]} ; 613$ 和 $700 \mathrm{~cm}^{-1}$ 处的特征峰可能来自氧化铁或氢氧化铁中 $\mathrm{Fe}-\mathrm{O}$ 的伸缩振动 ${ }^{[42]}$ 或者 beta分子篮晶体周围无定形 $\mathrm{SiO}_{2}$ 中 $\mathrm{Si}-\mathrm{O}$ 键的伸缩振动 ${ }^{[33,44]}$. ZSM-35分子篮骨架振 动的特征峰出现在 $325,425,800$ 和 $830 \mathrm{~cm}^{-1}$ 处 ${ }^{[43,45 \sim 48]}$; Fe/ZSM-5-HT 分子篮除了在 295, 380, 460 和 $800 \mathrm{~cm}^{-1}$ 处 出现归属于 MFI结构的特征峰以外, 还在 $526 \mathrm{~cm}^{-1}$ 处出 现特征峰, 可归属于低聚的 $\mathrm{FeO}_{x}$ 小簇中 $\mathrm{Fe}-\mathrm{O}-\mathrm{Fe}$ 的对称 伸缩振动 ${ }^{[22,49]}$.

将Fe/zeolite-HT样品在523 K下暴露在5.0\% $\mathrm{N}_{2} \mathrm{O} / \mathrm{He}$ 气氛中之后, Fe/ZSM-5-HT和 Fe/beta-HT分子篮在 867 $\mathrm{cm}^{-1}$ 处, Fe/ZSM-35-HT分子篮在 $730 \mathrm{~cm}^{-1}$ 处出现新的特 征拉曼谱峰(见图4(b)), 可分别归属于双核铁稳定的过 氧物种中 $(\mathrm{O}-\mathrm{O})$ 的对称伸缩振动 ${ }^{[34]}$ 和双核 $\mathrm{Fe}_{2}(\mu-\mathrm{O})_{2}$ 物 种中 $(\mathrm{O}-\mathrm{Fe}-\mathrm{O})$ 的对称伸缩振动 ${ }^{[23]}$. Fe/mordenite-HT分 子篮上则几乎观察不到双核铁物种形成.

\section{5. 铁活性位的浓度}

采用瞬态应答方法测定了 Fe/zeolite-C/HT样品上铁 活性位的浓度. 图5为Fe/ZSM-5-HT样品在 $1173 \mathrm{~K}$ 下 $\mathrm{He}$ 中预处理 $1 \mathrm{~h}$ 后, 再切换成 $5.0 \% \mathrm{~N}_{2} \mathrm{O} / \mathrm{He}$ 时的产物-时间应 答曲线. 可以看出, 在尾气中只检测到了 $\mathrm{N}_{2}$ 和 $\mathrm{N}_{2} \mathrm{O}$, 表明 $\mathrm{N}_{2} \mathrm{O}$ 在 $523 \mathrm{~K}$ 分解后生成的氧物种落在了 $\mathrm{Fe} / \mathrm{zeolite}$ 样品 的表面上. 用 Fe/zeolite-C样品进行瞬态应答实验则几乎 观察不到 $\mathrm{N}_{2}$ 的生成, 说明高温处理是铁活性位生成的一 个必要条件 ${ }^{[22]}$. 通过计算生成 $\mathrm{N}_{2}$ 的积分面积可以得到 单位质量Fe/zeolite样品中铁活性位的浓度, 结果见表2. 可以看出, Fe/zeolite-HT样品上铁活性位的浓度高低顺 序 为 $\mathrm{Fe} / \mathrm{ZSM}-35-\mathrm{HT}>\mathrm{Fe} /$ beta-HT $>\mathrm{Fe} / \mathrm{ZSM}-5-\mathrm{HT}>$ $\mathrm{Fe} /$ mordenite-HT. 这与FT-IR 结果一致, 即 $1874 \mathrm{~cm}^{-1}$ 处 红外谱峰的强度随着铁活性位浓度的增加而线性增加 (见图5(b)). 结合原位FT-IR谱, 可见拉曼光谱及瞬态应 答实验的结果可知, 在Fe/ZSM-35-HT, Fe/ZSM-5-HT和 $\mathrm{Fe} /$ beta-HT样品中, 骨架外铝稳定的双核铁物种是低温 $\mathrm{N}_{2} \mathrm{O}$ 分解的活性中心。在瞬态应答实验中, $\mathrm{Fe} /$ mordenite-HT上只有少量 $\mathrm{N}_{2}$ 生成, 这进一步证明在 $\mathrm{Fe}$ /mordenite-HT分子篮上几乎不存在低聚的铁物种.

\subsection{Fe/zeolite样品的催化性能}

图6(a)为Fe/zeolite-C/HT样品在 $\mathrm{N}_{2} \mathrm{O}$ 分解反应中 $\mathrm{N}_{2} \mathrm{O}$ 转化率随温度的变化. 由图可见, 对于 Fe/ZSM-35-C,
Fe/ZSM-5-C和Fe/beta-C催化剂样品, $\mathrm{N}_{2} \mathrm{O}$ 在 $700 \mathrm{~K}$ 以上 有明显的转化, 至 $773 \mathrm{~K}$ 时完全分解. Fe/mordenite-C样 品上 $\mathrm{N}_{2} \mathrm{O}$ 的分解反应从 $743 \mathrm{~K}$ 开始, 到 $853 \mathrm{~K}$ 完成. $\mathrm{N}_{2} \mathrm{O}$ 在 $773 \mathrm{~K}$ 时分解速率的大小顺序为 Fe/ZSM-35-C > Fe/ZSM-5-C > Fe/beta-C > Fe/mordenite-C (见表2), 并且 $\mathrm{N}_{2} \mathrm{O}$ 的分解速率随着 Fe/zeolite样品中孤立与寡聚铁物种 总含量的增加而线性增加 (见图 7(a)). 这表明在 Fe/zeolite-C样品中, 除较大的氧化铁纳米颗粒外的各种 铁物种都对 $\mathrm{N}_{2} \mathrm{O}$ 分解反应有贡献.

高温处理使所有Fe/zeolite样品的催化活性显著提 高, 结果见图6(b). $\mathrm{N}_{2} \mathrm{O}$ 转化率达到 $50 \%$ 时所需温度与 Fe/zeolite-C样品上相比, Fe/ZSM-35, Fe/beta, Fe/ZSM-5 和 $\mathrm{Fe} /$ mordenite样品上分别降低了 $80,50,40$ 和 $30 \mathrm{~K}$. Fe/zeolite-HT 样品在 $713 \mathrm{~K}$ 时 $\mathrm{N}_{2} \mathrm{O}$ 分解活性顺序为: Fe/ZSM-35-HT > Fe/beta-HT > Fe/ZSM-5-HT > Fe/mordenite-HT, 且 $\mathrm{N}_{2} \mathrm{O}$ 的分解速率随双核铁物种浓度的增加 而线性增加(见图7(b)). 这说明骨架外铝稳定的双核铁 物种是Fe/ZSM-35-HT, Fe/ZSM-5-HT和Fe/beta-HT催化 剂中稳态 $\mathrm{N}_{2} \mathrm{O}$ 分解的活性中心. 由于 $\mathrm{Fe} /$ mordenite-HT分 子篮上很难形成这种特殊结构的双核铁物种, 所以其高 温处理前后在 $\mathrm{N}_{2} \mathrm{O}$ 分解反应中的催化性能相差无几.

$\mathrm{Fe} /$ zeolite-HT样品在 $\mathrm{N}_{2} \mathrm{O}$ 分解反应活性上的差别与 双核铁物种的浓度有关, 而双核铁物种的形成与分子篮 的种类又密切相关. 离子交换法制备的分子篮样品中, 二价过渡金属阳离子一般落在分子篮中的 $\alpha, \beta$ 和 $\gamma$ 型阳 离子位上 ${ }^{[9]}$. 图8是FER, MFI, BEA和MOR分子篮中 $\alpha, \beta$ 和 $\gamma$ 型阳离子位. 其中 $\alpha$ 位位于两个五元环形成的六元环 中, 它位于 MOR, FER 和ZSM-5 分子篎十元环直孔道壁 上以及 BEA结构分子篮的多形体C中; $\beta$ 位位于 MOR腔 中扭曲的八元环中、FER腔中扭曲的六元环中、MFI结 构分子篮直孔道和Z型孔道交叉处的六元环中以及BEA 结构分子篮多形体 $\mathrm{A}$ 和 $\mathrm{B}$ 的六边形笼中的平面扭曲的六 元环中; $\gamma$ 位位于FER, MFI和MOR中的船型位中和BEA 结构分子篮多形体A和B的六边形笼中.

Dědeček课题组 ${ }^{[50,51]}$ 研究发现, 在Co/zeolites催化剂 体系中, 只有落在 $\alpha$ 和 $\beta$ 位上的 $\mathrm{Co}(\mathrm{II})$ 离子才能参与反应, 落在 $\gamma$ 位上的 $\mathrm{Co}(\mathrm{II})$ 离子不能参与反应. 高温处理的 $\mathrm{Fe} /$ zeolite样品上形成的双核铁位中的铁物种是Fe(II), 而 不是 $\mathrm{Fe}(\mathrm{III})$, 并且二价过渡金属阳离子在高硅分子篮中 的落位具有普适性. 此外, 一般认为, $\mathrm{O}_{2}$ 的脱附是 $\mathrm{N}_{2} \mathrm{O}$ 分 解反应的决速步骤 ${ }^{[25]}$, 相邻两个铁活性位之间较短的距 离更有利于表面氧物种的结合与脱附. 因此, Fe/zeolite 
样品中相邻两个铁活性位之间的距离与其催化活性密 切相关. 分子篮中相邻两个 $\alpha$ 位或相邻两个 $\beta$ 位的距离可 以认为代表了相邻最近的两个 Fe(II)离子的距离. 不同 分子篮中相邻两个 $\alpha$ 位或相邻两个 $\beta$ 位的距离是不同的. ZSM-35中相邻两个 $\alpha$ 位和相邻两个 $\beta$ 位的距离分别是 $0.54 \mathrm{~nm}$ 和 $0.61 \mathrm{~nm}{ }^{[50]}$. ZSM-5中相邻两个 $\alpha$ 位的距离是 $0.75 \mathrm{~nm}$, 但它们不是面对面存在的, 由此形成的双核铁 位不利于 $\mathrm{N}_{2} \mathrm{O}$ 分解反应的进行. 相邻两个 $\beta$ 位的距离是 $0.45 \mathrm{~nm}$ 并且它们处在直孔道与 $\mathrm{Z}$ 型孔道的交叉处, 有利 于 $\mathrm{N}_{2} \mathrm{O}$ 分解过程中反应物和产物的扩散 ${ }^{[10]}$. Beta分子篮 中落在多形体 $\mathrm{C}$ 中 $\alpha$ 位上的 $\mathrm{Fe}(\mathrm{II})$ 离子不能参与反应. Beta分子篮中相邻两个 $\beta$ 位的距离是 $0.75 \mathrm{~nm}$, 它们位于 多形体 $\mathrm{A}$ 和 $\mathrm{B}$ 中六边形笼的平面扭曲的六元环中心, 有 利于 $\mathrm{N}_{2} \mathrm{O}$ 分解反应中过渡态的形成, 所以只考虑落在多 形体 $\mathrm{A}$ 和 $\mathrm{B}$ 中相邻两个 $\beta$ 位上的两个 $\mathrm{Fe}(\mathrm{II})$ 离子 $^{[8]}$.

综上可知, 落在ZSM-35分子篮十元环直孔道中相 邻两个 $\alpha$ 位上的两个 Fe(II)离子和八元环孔道中相邻两 个 $\beta$ 位上的两个 $\mathrm{Fe}(\mathrm{II})$ 离子都容易形成双核铁位; 落在 beta分子篮多形体 $\mathrm{A}$ 和 $\mathrm{B}$ 中六边形笼中相邻两个 $\beta$ 位上的 两个Fe(II)离子容易形成双核铁位; 落在ZSM-5分子篮十 元环直孔道与 $\mathrm{Z}$ 型孔道交叉处相邻两个 $\beta$ 位上的两个 Fe(II)离子容易形成双核铁活性位.

另外一个能控制高硅分子篮中铁活性位形成的因 素是特定的阳离子位上成对铝的分布 ${ }^{[10,52]}$. 因为双核铁 活性位的形成需要在两个相邻阳离子位上的每个阳离 子位中都存在两个铝原子, 所以成对铝的分布能控制分 子篮中铁物种的结构和浓度 ${ }^{[10,52]}$. Dědeček等 ${ }^{[15 ~ 19]}$ 以 $\mathrm{Co}(\mathrm{II})$ 离子为探针, 利用紫外-可见漫反射光谱测定了分 子筛中特定阳离子位上成对铝存在的最大量.

ZSM-35 分子篮中, Co(II) 离子的最大交换量是 $\mathrm{Co} / \mathrm{Al}=0.31$, 所有的骨架 $\mathrm{Al}$ 原子中大约 $62 \%$ 是以成对的 形式分布在 $\alpha$ 和 $\beta$ 位的六元环 中 ${ }^{[10]} . \mathrm{Si} / \mathrm{Al}=10.5$ 的 ZSM-35 分子篮中, 单位质量的催化剂中有 $7.9 \times 10^{-4}$ $\mathrm{mol} / \mathrm{g}$ 的 $\mathrm{Al}$ 原子. $\mathrm{Fe} / \mathrm{Al}=0.33$ 时, 单位质量催化剂中有 $4.9 \times 10^{-4} \mathrm{~mol} / \mathrm{g}$ 的 $\mathrm{Al}$ 原子以成对的形式存在于 $\alpha$ 位和 $\beta$ 位 的六元环中 $\left(7.9 \times 10^{-4} \times 0.62\right) . \mathrm{Fe} / \mathrm{ZSM}-35$ 分子篮中, 大 约有 $5 \%$ 和 $85 \%$ 的 $\mathrm{Fe}(\mathrm{II})$ 离子分别落在分子篎的 $\alpha$ 位和 $\beta$ 位 上 $^{[18]}$, 并且相邻两个 $\alpha$ 位和相邻两个 $\beta$ 位上都可以形成双
核铁位. 因此, 单位质量催化剂中平均有 $2.5 \times 10^{-4}$ $\mathrm{mol} / \mathrm{g}$ 的铁离子可以形成双核铁位. 对于 $\mathrm{Si} / \mathrm{Al}=13$ 的 beta分子篮而言, 最大 $\mathrm{Co} / \mathrm{Al}$ 比为 0.45 (大约有 $90 \%$ 的骨架 $\mathrm{Al}$ 以成对的形式存在于六元环中), $55 \%$ 的 Co(II)离子落 在 $\beta$ 位上 ${ }^{[17]} . \mathrm{Fe} / \mathrm{Al}=0.33$ 时, 单位质量催化剂中有 $3.2 \times$ $10^{-4} \mathrm{~mol} / \mathrm{g}$ 的 $\mathrm{Al}$ 原子以成对的形式存在于 $\beta$ 位上, 则单位 催化剂中可以形成双核铁位的 Fe(II)离子的量为 $1.6 \times$ $10^{-4} \mathrm{~mol} / \mathrm{g} . \mathrm{ZSM}-5$ 中最大的 $\mathrm{Co} / \mathrm{Al}$ 比为 0.4 , 因此 $80 \%$ 的 骨架 $\mathrm{Al}$ 原子以成对的形式存在于六元环上, 其中 $50 \%$ 的 $\mathrm{Al}$ 落在 $\beta$ 位上 ${ }^{[53]}$. 也就是说, 最多有 $40 \%$ 的骨架 $\mathrm{Al}$ 原子 落在 $\beta$ 位的六元环上. $\mathrm{Si} / \mathrm{Al}=12.5$ 的ZSM-5分子篮中, 单 位质量催化剂中有 $6.7 \times 10^{-4} \mathrm{~mol} / \mathrm{g}$ 的 $\mathrm{Al}$ 原子; $\mathrm{Fe} / \mathrm{Al}=$ 0.33 时, 单位质量催化剂中有 $2.7 \times 10^{-4} \mathrm{~mol} / \mathrm{g}$ 的 $\mathrm{Al}$ 原子 以成对的形式存在于 $\beta$ 位上, 则单位质量催化剂中可以 形成双核铁位的 $\mathrm{Fe}(\mathrm{II})$ 离子的量为 $1.3 \times 10^{-4} \mathrm{~mol} / \mathrm{g}$. 总 之, 在Fe/ZSM-35-HT, Fe/beta-HT和Fe/ZSM-5-HT分子篮 中双核铁活性位的浓度顺序是 Fe/ZSM-35-HT> $\mathrm{Fe} /$ beta-HT $>\mathrm{Fe} / \mathrm{ZSM}-5-\mathrm{HT}$, 与它们催化 $\mathrm{N}_{2} \mathrm{O}$ 分解活性顺 序一致.

\section{4. 结论}

采用紫外-可见漫反射光谱、原位红外光谱及可见 拉曼光谱并结合瞬态应答方法研究了不同Fe/zeolite样 品在 $\mathrm{N}_{2} \mathrm{O}$ 分解反应中的催化性能. 结果表明, $\mathrm{Fe} /$ zeolite-HT样品在 $\mathrm{N}_{2} \mathrm{O}$ 分解反应中的活性顺序为 Fe/ZSM-35-HT > Fe/beta-HT > Fe/ZSM-5-HT > Fe/mordenite-HT, 与骨架外铝稳定的双核铁物种的浓度呈线性 关系。这说明 Fe/ZSM-35-HT, Fe/beta-HT 和 $\mathrm{Fe} /$ ZSM-5-HT催化剂上形成的双核铁位是 $\mathrm{N}_{2} \mathrm{O}$ 分解的活性 中心. Fe/mordenite-HT中的Fe物种主要以孤立铁离子的 形式存在, 因此其在 $\mathrm{N}_{2} \mathrm{O}$ 分解反应中的催化活性很低. 这种双核铁物种的形成与分子篮的种类又是密切相关 的. 结果表明, Fe/ZSM-35分子篮十元环孔道中相邻两 个 $\alpha$ 位和八元环孔道中相邻两个 $\beta$ 位都能稳定两个 $\mathrm{Fe}(\mathrm{II})$ 离子而形成能高效分解 $\mathrm{N}_{2} \mathrm{O}$ 的双核铁活性中心. Fe/beta 和 Fe/ZSM-5分子篮中只有落在相邻两个 $\beta$ 位上的两个 $\mathrm{Fe}(\mathrm{II})$ 离子才能形成参与 $\mathrm{N}_{2} \mathrm{O}$ 分解的高活性的双铁活性 中心. 